\title{
LA PRECOLONIZACIÓN Y LA COLONIZACIÓN FENICIA. EL PERÍODO ORIENTALIZANTE EN LA PENÍNSULA IBÉRICA. ESTADO DE LA CUESTIÓN
}

POR

\author{
J. M. BLÁZQUEZ \\ Real Academia dela Historia \\ (Madrid)
}

PALABRAS CLAVE: Precolonización, santuarios, colonización agrícola, atlántica, levantina, atristocracia, estelas grabadas.

KEY WORDS: Precolonisation, sanctuaries, agrarian colonisation, aristocracy.

\section{RESUMEN}

Se han propuesto en los últimos decenios algunas tesis novedosas sobre la colonización fenicia en Occidente, como la existencia de una etapa precolonial; la importancia de los santuarios; la colonización agrícola, en el Atlántico y en el Levante ibérico; el papel de la aristocracia de Tiro; la interpretación de las estelas grabadas.

\section{SUMMARY}

In the past recent years there are new thesis about the phoenizian colonisation in the West, as for example, the existence of a precolonial stage, the relevant role of the sanctuaries, the agrarian colonisation in the Atlantic shore of the Iberian Peninsula or in the Iberian Levant, the role of the tyrian aristocracy, etc. This article is a revision of all of them in the form of a summary.

En los últimos decenios ha cambiado radicalmente el panorama sobre la colonización fenicia en Occidente. Se ha excavado mucho más, no tanto como hubiera sido necesario y el número de profesionales dedicados a la arqueología ha aumentado bastante. Se han propuesto nuevas hipótesis de trabajo, que hace años eran inconcebibles. Se perfila con claridad las direcciones de la investigación en los próximos años, direcciones que son las que se pretenden examinar en este trabajo, que es un estado de la cuestión sobre los orígenes de la colonización fenicia al final de la Edad del Bronce. Tan sólo se comentan algunos trabajos más novedosos y algunas teorías más significativas.

\section{LA ETAPA PRECOLONIAL FENICIA}

Una de las novedades mayores de los últimos años es la existencia de una etapa precolonial fenicia.
En España el primer investigador que se refirió a una probable precolonización fenicia en Occidente fue Jaime Alvar ${ }^{1}$.

Recientemente varios autores han vuelto a completar esta tesis. Jaime Alvar ${ }^{2}$ es el primero que

${ }^{1}$ El problema de la precolonización en la generación de la polis, Imagen de la polis, ARYS, 8, 1997, 19-33. Sobre el final de la Edad del Bronce: M. Almagro et alii, Protohistoria de la Península Ibérica, Barcelona, 2001. M. C. Fernández Castro, Arqueología protohistórica de la Península Ibérica (siglos X a VIII a.C.), Madrid, 1988. M. Ruiz-Gálvez (coord.), La Edad del Bronce. Primera Edad de Oro en España. Economía e ideología, Barcelona, 2001. J. M. Blázquez, Fenicios, Griegos y Cartagineses en Occidente, Madrid, 1992, 69.72. Id., Tartessos y los orígenes de la colonización fenicia en Occidente, Salamanca, 1975. J. M. Blázquez, J. Alvar, C. G. Wagner, Fenicios y cartagineses en el Mediterráneo, Madrid, 1999. Como la bibliografía sobre los diferentes aspectos tratados en este trabajo es exhaustiva prescindimos de ella, pues se menciona en los diferentes estudios manejados. Agradezco a los profesores J. Alvar, J. Martínez Pinna, J. Abascal, A. González Prats, S. Perea, a los Drs. J. Mayer y J. Cabrero y a Don L. Ruiz Cabrero la importante bibliografía y sugerencias proporcionadas, incorporadas al texto.

${ }^{2}$ Comercio e intercambio en el contexto precolonial, $I$ Coloquio de CEFYP, Madrid, 2000, 27-34. M. Carrilero, Economía y sociedad en el sur peninsular en el periodo orientalizante, I. Coloquio del CEFYP, 203-214. Los fenicios introdujeron la metalurgia, objetos de hierro, el torno de alfarero. El autor sitúa un periodo previo a la colonización desde el s. $x$ a mediados del siglo viII a.C., que incluye los primeros contactos e intercambios con los fenicios. J.L. López Castro, Formas de intercambio de los fenicios occidentales en la época arcaica, I. Coloquio del CEFYP, 127-136. Para este autor el intercambio aristocrático va más allá del intercambio de dones y responde a determinadas estructuras sociales, que condicionarían la circulación de bienes. Se daría entre los años 800-700 a.C. El intercambio con los fenicios lo hacían una élite emergente en el periodo de formación, consolidada como aristocracia dominante en Tartessos, en la Alta Andalucía, en Levante y en el Norte de Marruecos. Llegarían con los grupos aristocráticos fenicios oficiales, metalúrgicos, orfebres, canteros , alfareros, etc., de lo que creemos hay confirmación arqueológica. Estos aristócratas fenicios se asentaron en Toscanos, Morro de Mezquitilla, Abdera y Sexi, lo que es muy probable. Grupos de la población autóctona pasarían a depender de los aristócratas fenicios, lo que parece posible. Las relaciones de intercambio de la aristocracia fenicia se establecía sólo con las élites autóctonas. Se daría una desigualdad del intercambio. Los fenicios intercambiaban objetos de gran calidad, como vestidos, 
matiza nuevamente el contenido del término precolonización fenicia en Occidente. Sugiere ahora emplear los términos: modo de contacto no hegemónico, caracterizado por intercambios sin ocupación territorial y sin sometimiento de la población autóctona, lo que significa sin explotación de recursos y sin obtener beneficios.

Este modo de contacto precolonial ejercido por los fenicios está confirmado o por Heródoto (1.2-3): «los fenicios, al llegar, pues, a territorio argivo, pusieron a la venta su cargamento, y, al cuarto o quinto día de su llegada, cuando ya lo tenían vendido casi todo, acudieron hasta la playa muchas mujeres y entre ellas la hija del rey; .... mientras las mujeres arrimadas a la popa del navío compraban los artículos que más eran de su agrado, los fenicios se alentaron mutuamente y se lanzaron sobre ellas. La mayoría de las mujeres, sin embargo, logró escapar, pero Io y otras fueron raptadas; las subieron entonces a bordo y se hicieron a la mar con rumbo a Egipto» (traducción de E. Schrader). Este texto de Heródoto confirma la tesis de Jaime Alvar.

El segundo modo de contacto es el llamado por este autor «modo de contacto sistemático», en el que la esencia del intercambio se establece en la explotación del trabajo ajeno mediante el sometimiento de la población autóctona y la organización del territorio para lograr un mejor control de los recursos y la captación masiva de beneficios. La precolonización y la colonización son excluyentes, según este autor, lo que creemos ser cierto, así como estas dos etapas. Somos de la opinión que el segundo modo de contacto no lleva automáticamente al sometimiento de la población autóctona; ni necesariamente a la ocupación del territorio, como lo indica Huelva que es un caso bien significativo en la primera etapa colonial, bien estudiada por M. Pellicer ${ }^{3}$. En esta ciudad se distinguen dos áreas, lo que obliga a considerar al yacimiento no como único, si no múltiple, con un extenso asentamiento iniciado del Bronce Final, tartésico precolonial, al menos desde el s. Ix a.C., emplazado en los cabezos de San Pedro, de la Esperan-

joyas y perfumes. Junto a esta forma de intercambio funcionaba el comercio empórico con base social más amplia. J.L. López Castro en esta fase concede gran importancia a los templos, lo que es totalmente seguro, de Cádiz y de Lixus, al culto de Astarté, protectora de los navegantes. Los cultos y los santuarios empóricos se localizan en las ciudades fundadas por los fenicios, lo que es totalmente cierto. Este comercio empórico potenciaría la producción de manufacturas. A partir del s. vir se desarrollaron la metalurgia del Hierro, la orfebrería, los bronces y marfiles, el consumo de vino y de aceite. En la segunda mitad del s. VII y primer tercio del VI aumentó la importación de productos del Mediterráneo central y oriental.

${ }^{3}$ Huelva tartésica y fenicia, RSF XXIV, 2, 1996, 119-140. za, del Cementerio Viejo, del Molino de Viento, y, quizá, de Mondaca y del Conquero, con un pobre urbanismo de cabañas esporádicas de barro. Este yacimiento ocuparía una extensión de 25 hectáreas a mediados del siglo viII. En la parte baja de la ciudad surgiría un emporion auténticamente fenicio semejante, con funciones diferentes, al del Castillo de Doña Blanca ${ }^{4} \mathrm{o}$ al de Sexi ${ }^{5}$. Esta población fenicia estaba en simbiosis con la población indígena que habitaba los cabezos con la que mantendría una economía de intercambio. En el siglo vil a.C. se convirtió en una colonia fenicia de gran importancia de unas 10 hectáreas de extensión, con una demografía de unos dos mil habitantes. La población era mixta, fenicia e indígena. Ambas poblaciones vivían pacíficamente. En el caso de Huelva no se puede hablar, seguramente, de un sometimiento de la población autóctona, ni de ocupación del territorio para lograr mayor control de los recursos y la captación masiva de beneficios. Los fenicios asentados en la parte baja de Huelva estaban interesados principalmente en metales que les proporcionaban los indígenas, pues Diódoro (5.35.3) afirma que los fenicios llenaron de metales, Grecia, Asia y todas las partes. Las minas, como las del Cerro Salomón, estaban explotadas por los nativos ${ }^{6}$, pero con técnicas traídas por los fenicios del Oriente, así como oriental es el tipo de construcción urbana.

S. F. Bondi en 1988 pensaba que la expansión fenicia vino motivada por la iniciativa de comerciantes particulares, quedando la función del estado relegada a un segundo término de escasa importancia.

Jaime Alvar ha reflexionado sobre el carácter de la iniciativa ultramarina fenicia, que en el primer milenio continúa siendo básicamente palacial, lo que es muy probable, aunque poco a poco se vislumbra una actividad individual fuera del territorio fenicio. Este autor se apoya, para defender el primitivo carácter palacial de la colonización fenicia, en las empresas conjuntas de Salomón e Hiram de Tiro sobre la construcción del temple (1 Re 5) o sobre la flota de Ofir (Jos. 2.10). A estos textos citados por Jaime Alvar podrían añadirse el de las naves de Tarsis que poseía Salomón (1 Re 10.22; 2 Cro. 9.21). Los que participaban en estas empresas trabajaban en régimen de dependencia.

Jaime Alvar piensa que las empresas mercantiles de los fenicios estaban en manos de la aristocracia, que era la única que controlaba los medios de producción y de comercialización, que no estaba diso-

${ }^{4}$ D. Ruiz Mata, El poblamiento fenicio del Castillo de Doña Blanca, Puerto de Santamaría, 1990.

${ }^{5}$ F. Molina Fajardo (ed.), Almuñécar. Arqueología e Historia I. Maracena 1986. 
ciada del poder político y que no se identificaba con los comerciantes autónomos, surgidos de la actividad comercial. Este autor encuentra una confirmación arqueológica a su tesis en que los primeros asentamientos en Occidente están ya amurallados y en que las tumbas más antiguas son de carácter aristocrático, como lo prueban los alabastrones de Sexsi o los hipogeos de Trayamar (fig. 1a). Este argumento es de peso para defender el carácter aristocrático de la colonización fenicia. Se puede añadir para confirmar la tesis de Jaime Alvar que la colonización etrusca es también de carácter aristocrático, como demostró ya Jorge Martínez Pinna ${ }^{7}$, al igual que la griega ${ }^{8}$. Según me sugiere Jorge Martínez Pinna ${ }^{9}$, la confirmación de este tipo de comercio aristocrático etrusco sería la tumba de la Nave en Tarquinia, con la representación de un gran navío, fechada a final del siglo vir a.C. Pertenece al

${ }^{6}$ A. Blanco, J.M. Luzón, D. Ruiz Mata, Excavaciones arqueológicas en el Cerro Salomón (Riotinto, Huelva), Sevilla, 1970.

${ }^{7}$ Aristocracia y comercio en la Etruria arcaica. J. Remesal, O. Musso (Coords.), La presencia de material etrusco en la Península Ibérica, Barcelona, 1991, 35-59. Sobre las relaciones Etruria-fenicios, véase: C. González Bellard, El comercio etrusco fencio, algunos apuntes, I Coloquio de CEFYP, 109113. Los inicios se datan en el s. VIII-640 a.C. El segundo período dura del 640 al 530 a.C. El lebete con prótomos de serpientes fechado en el segundo cuarto del s. viI a.C., hallado en la tumba Bernardini de Palestrina, al igual que los de Boston y Leiden, los de la tumba Bernardini y Castellani de Preneste y las copas de la tumba Regolini Gallasi de Cerveteri, datados en torno al 650 a.C., se han atribuido al mismo taller, asentado, probablemente, en Chipre, que trabajaba después del 700 a.C. A final del s. viII a.C., Chipre es una etapa del comercio oriental hacia Occidente. Bajo el influjo fenicio se desarrolló una toréutica chipriota que exportaba productos de lujo a Etruria, pero no a Tartessos. Los mismos ritos funerarios se documentan en Etruria, en Preneste, en Campania, en Salamina de Chipre y en Huelva. Junto a objetos importados es probable que trabajasen artesanos orientales, que introdujeron nuevas técnicas de joyería, como la granulación, también atestiguada en Occidente, Tesoro de la Aliseda, datado hacia el año 600 a.C., originando una rica producción local, sítula de Plikasna, hacia 650 a.C.. Seguramente llegaron de Siria la pátera de la tumba Bernardini, con detalles como el medallón central, que se repite en piezas de Nimrud, en Grecia y en la copa de Amatunte. Una segunda copa decorada con toros y caballos procede del mismo taller, al igual que la pátera de esta tumba (M. Cristofani, M. Martelli (Coord.), L'oro degli etruschi, Novara, 1983, 256-257, figs. $16-18,264$, figs. 39-40). Se han atribuido también a un taller de artesanos fenicios que trabajaban en Occidente, donde no han aparecido estos objetos de tan refinada técnica, probablemente porque la élite de la Península Ibérica era mucho menos numerosa y más atrasada. En general, $\mathrm{M}$. Grass, Trafics tyrreniens archaics, 1985. M. Cristofani (ed.), Il commercio etrusco arcaico, Roma, 1985.

${ }^{8}$ A.J. Graham, Colony and Modern City in Ancient Greece, Manchester, 1964, 29-39.

${ }_{9}^{9}$ M. Moretti, Nuovi monumenti della pittura etrusca, Milano, 1966, 198-199; S. Steingräber, Catalogo ragionato della Pittura etrusca, Milano, 1985 grupo más antiguo de pinturas de Caere, del tardoorientalizante. La nave es un motivó frecuente en la pintura funeraria etrusca de este periodo. Otros testimonios contemporáneos iconográficos son un piside de marfil de Chiusi, un vaso de Vulci hallado en la necrópolis de Polledrara y un ánfora etruscocorintia, conservada en el Museo de Louvre, testimonios todos con figuras de barcos. La nave podía aludir a príncipes comerciantes.

El profeta Isaías en el siglo viI a.C. (23.8) menciona en el oráculo de Tiro a «príncipes mercaderes, y a los negociantes príncipes de la tierra».

\section{SANTUARIOS}

También es idea acertada de Jaime Alvar la intervención sacerdotal en los orígenes de la expansión ultramarina, lo que equivale a admitir la tutela de Melqart y la organización estatal de las empresas coloniales. Para confirmar esta tesis podemos recordar algunos datos. Según Estrabón (III.5.5) los fenicios lo primero que hicieron al fundar Cádiz fue levantar el templo de Melqart, lo que indica la vinculación de los mercaderes de Tiro con el Herakleion de Tiro construido por Hiram I. El santuario de Cástulo (Jaén), ss. VII-VI a.C. (fig. 1b), cubierto de escorias, con un altar, con un toro de terracota, con una cocina y con los instrumentos mineros dentro de un ánfora, prueba el control de los santuarios en régimen de monopolio, de las explotaciones mineras ${ }^{10}$, exactamente como en Chipre, donde el dios de Enkomi, fechado a finales del s. XII a.C., se asienta sobre un lingote y un segundo de la misma procedencia datado a finales del s. XIII a.C. ${ }^{11}$. Estos dos dioses estaban, en el s. XII a.C., conectados con la metalurgia.

La industria del cobre se encontraba en Chipre bajo la protección divina debido a la importancia de la producción y explotación de este metal, al igual que sucedía en Timna, en Palestina, a final de la Edad del Bronce ${ }^{12}$ y en Keá, en el Egeo. La vincu-

${ }^{10}$ J. M. Blázquez, J. Valiente, Cástulo III, Madrid, 1981; J. M. Blázquez, M. P. García-Gelabert, F. López Pardo, Cástulo V, Madrid, 1985; J.M. Blázquez, M. P. García-Gelabert, Cástulo, ciudad iberorromana, Madrid, 1994, 448-456. Sobre la arquitectura de este período: D. Ruiz Mata, S. Celestino (eds.), Arquitectura oriental y orientalizante en la Península Ibérica, Madrid, 2001. J. L. Escacena, Fenicios a las puertas de Tartessos, Complutum, 12, 2001, 73-96. F. Mayer, C. Tavares da Silva, Le site d'phèniciens d'Abul (Portugal), comptoir et sanctuaire, París, 2000.

11 V. Karageorghis, Cyprus fron the Stone Age to the Romans, London, 1982, 102-104. Id., Ancient Cyprus. 7000 Years of Arts and Anchaeology, London, 1981, 94-95.

${ }^{12}$ B. Rothenberg, Timna. Valley of the Biblical Copper Mines, Londres, 1972. D. Valbelle, Ch. Bonnet, Le sanctuaire d'Hator, maitresse de la turquoise, París, 1966. 

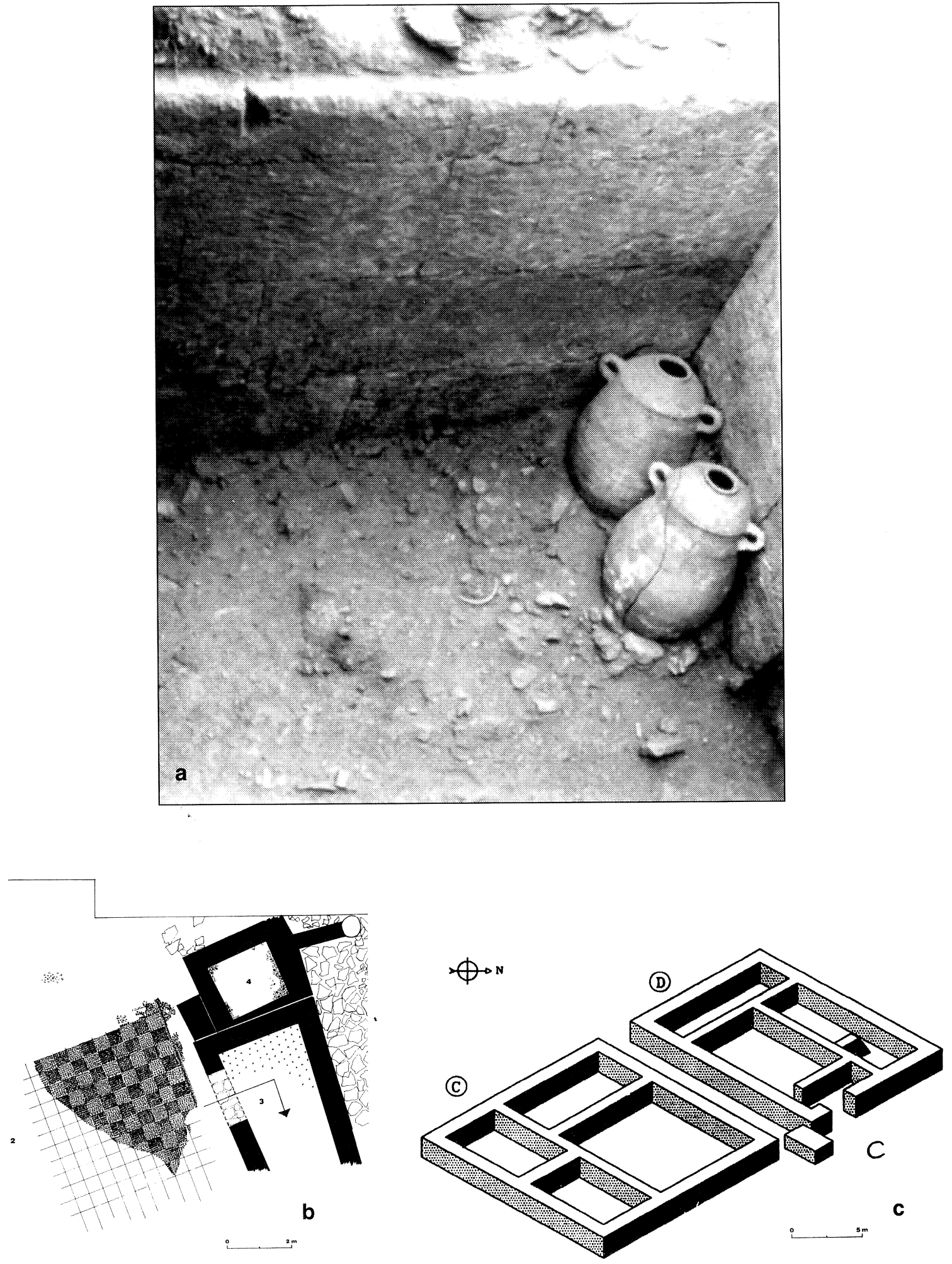

Fig. 1a. Tumba de Trayamar, Málaga, según H. G. Niemeyer y H. Schubart; b. Santuario de Cástulo, Jaén, según J. M. Blázquez; c. Santuario de Montemolín, Marchena (Sevilla), según M. Belén. 
lación de la metalurgia con la religión es evidente en el santuario de Myrtou-Pigadles, en el templo de Afrodita en Palaepafos, donde han aparecido lingotes votivos de cobre, como en Cástulo y en el santuario de Golgoi. El caso más claro es el de Kition, donde los templos comunicaban con los talleres que trabajaban el cobre ${ }^{13}$. El templo 1 de esta localidad estaba dedicado a una diosa de la fertilidad. En el periodo fenicio fue reconstruido y consagrado a Astarté. Una figurilla de Astarté, guardada en el Ashmolean Museum de Oxford, fechada en el s. XII a.C., representa a la diosa sobre un lingote ${ }^{14}$.

La tutela de Melqart, principalmente a través de los sacerdotes del Herakleion gaditano ${ }^{15}$ es perfectamente defendible. El Herakleion gaditano funcionaba como un karum al igual que los templos del Oriente. Un Herakleion debía haber en Huelva, según la tesis de M. Pellicer y a él pertenecerían las dos imágenes, más bien de Melqart que de Reseph, halladas en la ciudad. Estrabón (3.5.5) menciona una isla consagrada a Melqart junto a Onoba, y un segundo, quizá, en pleno estrecho de Gibraltar ${ }^{16}$. M. Belén ha estudiado recientemente los santuarios y el comercio fenicio en Tartessos ${ }^{17}$. Algunos de estos santuarios son de fecha posterior a los orígenes de la colonización fenicia en Occidente, como los de Monte Algaida. Se datan en fecha arcaica los de Cerro de San Juan, Coria del Río, de la segunda mitad del s. vII a.C., con altar en forma de piel de toro extendida. El color rojizo coral indica que se trata de un santuario fenicio, que se asentaba sobre otro más antiguo, también pintado de rojo. Se ha supuesto que podía ser el Mons Cassius de la Ora Marítima de Avieno (259), promontorio consagrado a Baal. Es interesante señalar un dato recogido por M. Belén, que el altar de piel de toro se encontraba en compañía de abundantes restos de bóvidos. En contra de lo que se ha afirmado por nosotros, los altares no se colocaban sobre representaciones de lingotes, si no sobre una piel de toro, lo que vendría confirmado, en el caso del Cerro de San Juan, en los abundantes restos de bóvidos. Las imágenes citadas de Enkomi no estarían según J. Mayer ${ }^{18}$

13 V. Karageorghis, Kition. Mycenaean and Phoenician Discoveries in Cyprus, Londres, 1976, 96-107, lám. XIV.

${ }_{14}$ V. Karageorghis, Kition(cit. n. 13), fig. 56. Id., Ancient Cyprus (cit. n. 11), 95.

${ }_{15}$ J. M. Blázquez, Imagen y mito. Estudios sobre religiones mediterráneas e iberas, Madrid, 1977, 17-28.

${ }^{16}$ M. Belén, J. Pérez López, Gorham's Cave. Un santuario en el Estrecho. Avance al estudio de los materiales cerámicos. Actas del IV Congreso Internacional de Estudios Fenicios y Púnicos II. Cádiz, 531-536.

${ }^{17}$ I Congreso del CEFYP, 293-312.

${ }^{18}$ El lingote en rama chipriota o de piel de toro: símbolo divino de la antigua Iberia, Congreso Internacional Fiestas sobre un lingotes, si no sobre una piel de todo, ya que en el santuario, han aparecido muchos bucráneos, y los devotos o sacerdotes se ponían sobre la cabeza máscaras de toro en las ceremonias de culto ritual, que remontan a la Edad del Bronce, como lo confirma una terracota hallada en Limassol, M. Amathus, datada en el s. vi a.C. Se trata de adquirir las cualidades del toro, la fertilidad y virilidad ${ }^{19}$. En una segunda terracota recogida en el templo de Apolo en Curion dos sacerdotes o devotos se colocan la máscara de toro sobre la cabeza ${ }^{20}$. Bucráneos han aparecido en el atrio del gran templo fenicio de Chipre ${ }^{21}$. La aparición de estos bucráneos asemejan mucho los templos de Kition y de Coria del Río.

Un santuario fenicio, de mediados del siglo vIII a.C., es el de El Carambolo, dedicado a Astarté. El ritual sería el mismo que el seguido en el santuario de Cástulo (fig. 1b): ofrendas de vasos de mejor calidad, que los usados en el poblado, estrellados contra el suelo. Se desconoce el contenido de ellos en ambos santuarios, líquidos o hierbas.

El topónimo Híspalis es fenicio según algunos filólogos y podría ser una fundación fenicia. M. Belén apuntó muy acertadamente la aparición de pequeños betilos, posibles imágenes anicónicas de la divinidad, lo que confirmaría el carácter fenicio del santuario. También es acertada la hipótesis de trabajó de M. Belén de que El Carambolo Bajo no es un poblado tartésico sino un santuario fenicio, consagrado a Astarté, y que el fondo de cabaña de El Carambolo Alto es un pozo o un foso ritual. Es un bothros como el descubierto en el santuario de Cástulo.

Otros dos santuarios recordados por M. Belén, serían los de Montemolín (fig. 1c) en el término de Marchena. El más antiguo se fecha entre los siglos VIII y VII a.C. y el segundo entre mediados del siglo VII y los principios del siglo vi a.C. Es un edificio considerado como lugar de sacrificio de suidos, de bóvidos y de ovicápridos, parte de cuyas carnes se consumían en banquetes rituales, o se ofrecían a la divinidad, y parte se destinaba al abastecimiento doméstico o al intercambio, ritual seguido en el santuario de Cástulo, que procede del Oriente según se indicó al estudiar este santuario.

de Toro y Sociedad, Sevilla (en prensa). Nada tiene de extraño esta interpretación debido a la gran importancia del toro en todas las culturas mediterráneas antiguas. A. Ribas (coord.), El toro i la mediterrania, Palma de Mallorca, 2000.

${ }^{19}$ V. Karageorghis, Cyprus, 143. Id., Ancient Cyprus (cit. n. 11), 157. Máscaras de toro llevan sobre la cabeza tres figuras en el santuario de Vounous, datado a comienzos de la Edad del Bronce III (V. Karageorghis, Ancient Cyprus, 45).

${ }^{20}$ V. Karageorghis, Kition (cit. n. 13), fig. 82. 
Otros datos recogidos por M. Belén apuntan, igualmente, a prototipos cultuales venidos del Oriente, traídos por los fenicios, como son los hogares del patio y las vasijas rotas después de preparar y cocinar los alimentos. Las partes de las carnes dedicadas a la divinidad se quemaban, probablemente, en una habitación donde se han recuperado lotes de cerámicas fabricadas a torno poco comunes, como vasijas decoradas con figuras. Los exvotos cerámicos eran siempre de mejor calidad que los vasos usados en los poblados. En el entorno del cuarto edificio se halló un pozo votivo, que contenía mezclados huesos de animales, abundantes cenizas con cerámicas de calidad, algunas de ellas decoradas con motivos figurados, como era de rigor en estos bothros.

En Carmona en un lugar a espaldas del Palacio del Marqués de Saltillo, se descubrió un santuario fechado entre mediados del siglo vII y mediados del siglo v a.C., con bancos adosados y el empleo de pintura roja, típico de las construcciones fenicias. Se recuperaron tres pithoi decorados con motivos de tradición oriental (fig. 2a) pintados de rojo y negro. También se encontraron cucharillas de marfil. Piensa M. Belén, apoyada en la presencia de vasos para beber, de cuencos y de vasos caliciformes, que debían celebrarse rituales de libación y de ofrendas de vino, lo cual es más probable, pues el vino desempeñaba papel importante en la religión judía, cuyos rituales estaban próximos a los fenicios ${ }^{22}$. Se mandaba su utilización de las libaciones de los sacrificios (Ex. 29.40; Num. 15.5-7) y a los sacerdotes cuando oficiaban (Le. 10.9; Num. 6.3). De todos estos datos deduce M. Belén, siguiendo a otros autores, que en el suroeste hispano, el comercio fenicio utilizó una auténtica red de santuarios excelentemente distribuidos en las rutas de acceso a las fuentes de los recursos, en los que estaban interesados los fenicios. Las divinidades veneradas en estos santuarios serían Melqart, Astarté y Baal. En esta red de santuarios, el Herakleión gaditano desempeñaba el primer papel, al igual que en la isla de Huelva consagrada a Melqart, que sería un santuario al aire libre, que según M. Pellicer controlaría la obtención del estaño atlántico. Los santuarios citados del cerro de San Juan y del Carambolo estarían en función de la navegabilidad por el Guadalquivir, por donde llegaban a Cádiz los minerales de Sierra Morena, y los excedentes agropecuarios del Valle. Sin negar que todos estos santuarios citados tengan un

\footnotetext{
21 V. Karageorghis, Kition (cit. n. 13), figs. 79-81.

${ }^{22}$ En el culto de Ugarit el vino desempeñaba un papel importante. J. A. Zamora, La vid y el vino en Ugarit, Madrid, 2000, 531-645.
}

carácter comercial, para nosotros están todos ellos enclavados en la zona de la colonización fenicia agrícola, que no sólo se asentó en la costa, si no en las fértiles orillas del Guadalquivir.

El carácter fenicio de todos estos santuarios, bien patente en los rituales, y en las cerámicas, en el uso de pintura roja, indica que se trata de verdaderos santuarios fenicios, no de santuarios indígenas influidos por la religión fenicia. Son los santuarios de fenicios asentados en el interior, de colonos dedicados a la agricultura y, posiblemente, también al comercio.

Esta colonización, seguramente, responde a la fuerte presión asiria sobre las poblaciones de Siria, Fenicia e Israel, que les obligó a emigrar a Occidente. La existencia de esta colonización agrícola, ya barruntada por Bonsor, es una de las ideas más fecunda con la que se trabaja en los últimos años, que explica satisfactoriamente muchos fenómenos del valle del Guadalquivir, como la presencia de estos santuarios, de los marfiles de Carmona, de la decoración fuertemente oriental y de la cerámica, etc. Los minuciosos estudios que se realizan el actualidad sobre cerámicas supuestamente tartésicas, sugieren que no son tartésicas sino fenicias. En Occidente hay una verdadera colonización fenicia, según defienden Jaime Alvar y C. G. Wagner, por todo el valle del Guadalquivir de tierras muy fértiles, además de por otras zonas como la serranía de Ronda y la costa malagueña, que llevan a disminuir considerablemente la importancia del reino de Tartessos. Lo que se consideró productos de este reino y del periodo orientalizante serían, en su casi totalidad, productos fenicios utilizados por poblaciones fenicias. Esta idea no es negar que hubiera entre estos colonos fenicios poblaciones indígenas y que se diera una fuerte aculturación. La presión asiria que motivaría la emigración del campesinado a Occidente ha quedado bien descrita gráficamente en el obelisco negro de Salmanasar III (858-824) ${ }^{23}$ con escenas de portadores de tributos, entre las que figuran las de Jehu (842-814), hijo de Omri (882-871); o las campañas del mismo monarca asirio en Fenicia, como la entrega de tributos y la conquista de Tiro; el ataque a Hazuzu; la campaña al norte de Siria contra la ciudad de Dabigu, y el asalto a la ciudad de Hamath en las puertas de bronce de Balawat ${ }^{24}$ y los saqueos de Astartu, la bíblica Ashtaroth, ciudad consagrada a

${ }^{23}$ J. B. Pritchard, The Ancient Near East in Pictures Rela ting to the Old Testament, Princeton, 1969, 2990-291, figs. 351-355. R. D. Barnett, A. Lorenzi, Assyrische Skulpturen, Recklinghausen, 1975, 43.

${ }^{24}$ J. B. Pritchard, op. cit. (n. 23), 291-293, figs. 356-366. 
Astarté, citada ya en el Génesis 19.5, en un relieve de Tiglath-Pileser III (744-727); el asalto de Senaquerib (704-681) a Laquis ${ }^{25}$.

\section{FECHA DE LA PRECOLONIZACIÓN}

La fecha de la etapa precolonial es difícil de precisar. En nuestra opinión pudo durar varios siglos, como se desprende del trabajo de M. Almagro-Gorbea, citado más adelante. Existió en el siglo $\mathrm{x}$, como apunta Jaime Alvar. A ella aludirán Heródoto (4.196), la Ora Marítima y el Pseudo Escilas (112). El fenómeno de la precolonización fenicia fue parecido al de la colonización griega en la que los elementos aristocráticos dejaron poco a poco paso a un comercio más complejo, que desembocaría en las modalidades empóricas o de apoikia. Este periodo no tendría mercados o colonias. En el comercio en manos de la aristocracia el resto de la población quedaba marginada.

\section{LOS FENICIOS EN LA COSTA ATLÁNTICA. LA COLONIZACIÓN AGRÍCOLA}

En la costa atlántica de la Península Ibérica se desarrollaría primero, según Jaime Alvar, una actividad comercial no hegemónica que terminaría sustituida por contactos sistemáticos. Este autor menciona que desde Cádiz los fenicios iniciaron un proceso de ocupación territorial por todo el mediodía peninsular. Esta ocupación territorial para nosotros es la colonización agrícola fenicia.

\section{FUENTES DE SUMINISTRO DE METALES PARA ORIENTE}

En un segundo trabajo, Jaime Alvar ${ }^{26}$ matiza más su pensamiento. En los tributos pagados por los fenicios a Tiglath Pileser I (c.1116-1078), hacia el año 1100 a.C., no se menciona metales, quizá por no haberse iniciado el proceso de expansión ultramarina, o porque los metales aun no eran los bienes de prestigio. Sin embargo, Bikay, una de las mejores especialistas en cerámica chipriota, hace años, me indicó que en Málaga había dos vasos que procedían

\footnotetext{
${ }^{25}$ J. B. Pritchard, op. cit. (n. 23), 293-294, figs. 372-374

${ }^{26}$ Interacción económica y social de los fenicios en la tartésida, F. Wulff, G. Cruz Andreotti y C. Martínez Mata (eds.), II Congreso de Historia Antigua de Málaga, Comercio y Comerciantes en la Historia Antigua de Málaga (siglos VIII a.C.- año 711 d.C.), Málaga, 2001, 11-37.
}

de Tiro y que se fechaban en el siglo x. En la primera mitad del siglo IX a.C., Assurnassipal, entre los tributos fenicios, menciona la plata, el oro, el estaño y el bronce, metales todos que podían proceder del Occidente, además de telas multicolores de lino que tejían con gran habilidad la mujeres fenicias, muebles de madera y quizá dientes de animales marinos. A mediados del siglo, Salmanasar III recibe oro, plata, estaño y cobre, lanas azules y rojas. Tiglathpileser III, recoge 150 talentos de oro. Generalmente se admite que los tributos de metales, todos los cuales se producían en grandes cantidades en Occidente según Estrabón (3.2.8), los obtenían los fenicios en Occidente. El geógrafo griego afirma que hasta ahora, ni la plata, ni el oro, ni el cobre, ni el hierro nativos se han hallado en ninguna parte de la tierra tan abundantes y excelentes. Jaime Alvar examina más a fondo esta teoría frecuentemente admitida. Los metales entregados por los fenicios a comienzos del IX a.C. a Assurnasirpal, son anteriores a los primeros documentos fenicios descubiertos en la Península Ibérica y antes de la alianza político-comercial de Salomón (c. 965-928) e Hiram de Tiro para explorar el Mar Rojo, pero esta hipótesis de trabajo no la encontramos defendible. Jaime Alvar no cuestiona el móvil económico como fundamento de la colonización fenicia en el Mediterráneo, señalado por el texto ya citado de Diódoro al que se puede añadir Ps. Arist. (135).

Gran mérito de Jaime Alvar es llamar la atención a la investigación española sobre las posibles fuentes de aprovisionamiento por los fenicios de metales en Oriente, tema que se ha tratado recientemente en la investigación hecha fuera de España. En este punto insiste igualmente C.G. Wagner, como veremos.

De estos estudios se deduce que Anatolia, a través del puerto de Tarso de Cilicia, suministraba plata, hierro, estaño y plomo. Los fenicios visitaban asiduamente no sólo Tarso de Cilicia, si no el interior de Anatolia, como Dumuztepe y Karatepe, desde comienzos del s. IX a.C. data la penetración fenicia en Sam'al, uniendo Gurgun con el valle del Orontes y convirtiendo a los fenicios en la bisagra entre el interior y el mar, al que se llegaba a través de Al Mina.

De Asia Menor y Chipre los fenicios importaban hierro y cobre, y del Egeo plata, esclavos y, probablemente, alimentos; y de Ofir, oro. Piensa este autor que las empresas fenicias destinadas a obtener recursos metalíferos en Occidente serían objetivos sobreañadidos a la estructura comercial fenicia. En el momento de máxima presencia fenicia en Occidente, en el segundo cuarto del s. viII a.C., los yacimientos de Anatolia estarían degradados por la ex- 
plotación de los minerales de Urartu, lo que obligaría a los fenicios a buscar nuevos lugares productores de metales. El Occidente debía ofrecer notables garantías y beneficios para justificar un largo viaje no sólo en la fase de control hegemónico, sino en la etapa anterior. Hay que recordar, contra la tesis de Jaime Alvar, que un excelente conocedor de la Prehistoria y de la Protohistoria de España, W. Schüle demostró, basado en cartas de navegación, que en el Mediterráneo, en determinadas épocas, por el régimen de los vientos, se podía navegar con gran rapidez y seguridad en ambas direcciones.

Sin negar que los fenicios obtuvieran metales de Anatolia en las fechas propuestas por Jaime Alvar, nos inclinamos a admitir la tesis del hispanista $\mathrm{M}$. Koch ${ }^{27}$ de que la gran abundancia de plata mencionada en la Biblia (1Re. 10.22; II Cr. 9.14.24.27) en tiempos de Salomón, no podía proceder de ninguna otra parte que del Occidente.

\section{CAUSAS DE LA COLONIZACIÓN FENICIA. SI- TUACIÓN DE LA ARISTOCRACIA}

Jaime Alvar ha llamado la atención para explicar la colonización fenicia en Occidente, basado en el relato de la fundación de Cartago, en el carácter urbano de los establecimientos comerciales y en la fisonomía de los enterramientos de Lagos, Almuñecar y Trayamar, en los cultos coloniales, en las tensiones internas de la aristocracia fenicia, que potenciaría el nuevo carácter hegemónico de los contactos interculturales. Esta idea significa un gran avance en la interpretación de la colonización fenicia en Occidente. La aristocracia fenicia deseaba mantener el control de los medios de producción y comunicación, y la supervisión en los extremos de la red de intercambios.

Esta aristocracia estaba desplazada de los medios políticos. A ella alude el ya citado texto de Isaías.

\section{AUMENTO DE POBLACIÓN EN OCCIDENTE}

Tiene razón Jaime Alvar en que la población fenicia fue más elevada que lo que generalmente se supone; principalmente existió una colonización asentada en las orillas del Guadalquivir. Las causas de esta colonización, en nuestra opinión, fueron principalmente la presión asiria sobre Siria, Fenicia y Palestina, a la que ya hemos aludido, más bien que a las causas mencionadas por Jaime Alvar, que

${ }^{27}$ Zur frühen jüdischen Diaspora auf der Iberischen Halbinsel, Homenaje a García y Bellido III, Madrid, 1977, 225254 . también pudieron desempeñar un papel complementario, como las deficiencias estructurales de las ciudades fenicias metropolitanas, que originaban desequilibrios demográficos, los agricultores desarraigados, la concentración de los medios de producción, la intensificación de la explotación del trabajo ajeno, y la existencia de una aristocracia secundaria. La presión asiria motivaba desplazamientos de población, además de saqueos y de pago de tributos, que se representan en los citados relieves de las puertas de Balawat con filas de cautivos procedentes de Hazazu y Astartu. En un relieve de Tiglathpileser III, los cautivos son transportados en carro ${ }^{28}$. Alrededor del año 735 , Tiglathpileser III deportó los habitantes de Ashtaroth en compañía de otros muchos de Galaad y de Galilea (2Re. 15.29). A lo largo de siglo y medio fueron enviados a Mesopotamia en convoyes los habitantes de Israel y de Judá por los vencedores.

El reino de Israel cayó en poder de los asirios y desapareció de la historia en 721. Sus habitantes fueron reemplazados por paganos deportados de Oriente. La capa alta de la sociedad fue llevada a Mesopotamia (2Re. 17.5-6; 24-25) unos 125/135 años antes de que fueran desterrados los habitantes de Judá. En el año 587 Nabucodonosor de Babilonia penetró en Jerusalén, deportó al rey Sedecías (2Re. 25.3-7; Je. 39.2-7; 52.6-11), saqueó, incendió y desmanteló la ciudad y el templo, mató y deportó a la nobleza civil y sacerdotal en el 586, permaneciendo en la ciudad sólo el estrato bajo de la población (2Re. 25.3-10.1316; 2Cro. 36.17-19; Je. 39.8; 52.12-14). Samaría después del 721 a.C. se convirtió en la tierra de colonización y distrito del Imperio asirio (2Re. 17.29; Esd. 4.10). Estas frecuentes campañas asirias explican satisfactoriamente la colonización agrícola en Occidente y el aumento de la población.

La aristocracia fenicia asentada en Occidente reprodujo los sistemas importados de la metrópolis. Jaime Alvar concede una gran importancia y significado a la muralla que rodeaba en las ciudades, lo cual pueden ser cierto, pero no hay que olvidar que la muralla está documentada unos 1500 años antes en la Península Ibérica: Los Millares, Vilanova de San Pedro, Orce etc.

\section{EL HERAKLEIÓN GADITANO Y LA COLONI- ZACIÓN FENICIA}

Piensa Jaime Alvar que el Herakleión gaditano estaba organizado en la estructura político-adminis-

\footnotetext{
${ }^{28}$ J. B. Pritchard, op. cit. (n. 23), 293, fig. 367.
} 
trativa de Tiro, y dirigido por la aristocracia sacerdotal, lo cual es muy posible, pero no hay huellas de ello en las fuentes. Siempre mantuvo Cádiz unas vinculaciones con Tiro, como prueban los dos sarcófagos hallados en la ciudad, fechados en el siglo Iv a.C., y la caja de un tercero, que estuvo mucho tiempo tirada en la playa de Cádiz. Sí parece posible, como en el caso de Cartago, una cierta dependencia religiosa de las colonias fenicias occidentales y, principalmente, del Herakleión gaditano con respecto a la monarquía de Tiro y más con el Herakleión de esta ciudad. Los autores que han transmitido datos sobre el Herakleión gaditano, como Estrabón (III.5.5-7), el autor del Bellum Hispaniense, Silio Itálico (III.14-32) que describe los rituales y recoge datos sobre el sacerdocio, Filostrato ( $V$. Apoll. Tian. 5.4.5) no mencionan ninguna jerarquía en el santuario, lo cual no prueba que no la hubiera. Sí es probable, como apunta Jaime Alvar, que los sacerdotes gaditanos estuvieran vinculados con las personas que ejercían el poder. Tampoco se documentan a finales de la República Romana, fincas, bosques, pesquerías, minas o esclavos en propiedad del Herakleión gaditano, tampoco en el templo de Jerusalén, que tenía, al igual que el gaditano, cuantiosas riquezas (1Mac. 1.20-24) y que un templo de Elam ${ }^{29}$ (I Mac. 6.2). En el establecimiento de las colonias fenicias en Occidente, el oráculo de Tiro, que debió ser el del Herakleión de la ciudad, desempeñó un papel importante (Str. III. 4.5). Los tres viajes de tanteo hasta establecerse en Cádiz podrían aludir a una etapa precolonial. Algunos datos sobre templos del Oriente indican lo que debía ser la importancia mercantil del Herakleión y su funcionamiento. «El templo de Afrodita en Comana Póntica según Estrabón (XII.3.36) poseía un importante mercado para las poblaciones que llegaban de $\mathrm{Ar}$ menia. Aquí se encontraban por todas partes imágenes de la diosa, ciudadanos y campesinos, hombres y mujeres para participar en la fiesta. Aquí se fijaban por obediencia a un voto y realizaban sacrificios a la diosa. Sus habitantes vivían en el lujo. Todas las tierras eran viñedos, y muchas mujeres comerciaban con su cuerpo, consagradas a la diosa. En ciertos aspectos esta ciudad es una pequeña Corinto, pues también aquí había gran número de prostitutas consagradas a Afrodita, cuya fiesta provocaba un desplazamiento considerable de la población, dando lugar a numerosas celebraciones. Los comerciantes y los soldados gastaban generosamente su dinero».

${ }^{29}$ E. Lipinski (ed.), State and temple economy in the Ancient Near East, Louvain, 1974.
El segundo texto de Estrabón (XII.5.3) dice: «Pesinunte es el mercado más importante de esta ciudad. La ciudad tiene un santuario consagrado a la Madre de todos los dioses, objeto de una gran veneración. Aquí se la adora bajo el nombre de Agdistis. Sus sacerdotes eran verdaderos dinastas, que se aprovechaban de su cargo para enriquecerse ostensiblemente. Aunque su prestigio ha disminuido hoy día, sin embargo, la actividad mercantil del templo se mantiene» (traducción de S. Perea).

La situación del Herakleión gaditano debió ser idéntica. El Artemision de Efeso estaba rodeado de artesanos, que vendían imágenes de la Artemis Efesia (Hech. 19.23-27).

La existencia de una aristocracia no la juzgamos excluyente de comerciantes autónomos.

Los alabastrones como los de Sexi, según sugiere Jaime Alvar, es muy probable, que trajeran vino $\mathrm{o}$ aceite para los rituales religiosos, pues vino y aceite se utilizaban en ellos entre los judíos. El aceite se usaba en los ritos de consagración (Ge. 28.18; 31.13; 35.14; Ex. 25.6; 27.20; 29.2; Je. 6.20; 8.12), y para los sacrificios (Ex. 29.40; Le. 2.1-5. 7). Uno de los alabastrones de Sexi lleva escrita la palabra aceite. La actividad comercial de la aristocracia y de los comerciantes autónomos no corresponde a la fase inicial y no estaría desvinculada de palacio.

\section{EL CASO DE LA COLONIZACIÓN EN CHIPRE}

Como indica Jaime Alvar, el caso de la colonización fenicia en Chipre, arroja luz sobre la colonización fenicia en Occidente. A la isla llegaron gentes procedentes Tiro, de Sidón, de Arvad, ya desde el siglo x. Las dos fases, que se han identificado en Chipre, se debieron repetir en la Península Ibérica. La primera careció de establecimientos permanentes, no así la segunda, a partir de la segunda mitad del siglo IX, fundandose ahora ciudades como $\mathrm{Ki}$ tion. Las empresas coloniales de estas segunda etapa estaban ya bien organizadas en manos de la aristocracia. Con el tiempo, se daría una coparticipación indígena de la empresa mercantil fenicia, que tendría a la larga fuertes repercusiones sociales y económicas en la región, lo que explicaría satisfactoriamente la existencia de Cancho Roano ${ }^{30}$, y de Pozo Moro en fechas más recientes.

${ }^{30} \mathrm{~S}$. Celestino, Intercambio y estructuras comerciales en el interior de la Península Ibérica. I. Coloquio del CEFYP, 137 151. También, R. López Domech, Los fenicios en el interior, I. Coloquio del CEFYP, 189-197. 
LOS FENICIOS EN EL INTERIOR DE LA PENÍNSULA IBÉRICA: CANCHO ROANO Y POZO MORO

Para nosotros el primero es un establecimiento fenicio sagrado reconstruido varias veces como lo indica que está pintado de rojo. En Pozo Moro se representan mitos como los sacados del poema de Gilgamesh, a Astarté y al Cronos fenicio ${ }^{31}$. El arte del relieve plano tan ajeno a las características del arte griego prueba que no sólo el simbolismo, sino el arte, se debe a artesanos orientales. El personaje enterrado podía ser un fenicio, o un reyezuelo indígena, fuertemente semitizado, enterrado en torno al 500 a.C. La necrópolis, sin embargo, es indígena.

\section{LAS ESTELAS GRABADAS. SISTEMAS DE CONTROL}

S. Celestino ha aportado recientemente algunos datos de gran novedad sobre los intercambios y las estructuras comerciales en el interior de la Península Ibérica, que son muy importantes y que es necesario recoger.

El primer lugar, ha señalado $\mathrm{S}$. Celestino los primeros sistemas de control comercial, lo que no se había hecho hasta ahora. Se trata de unos hoyos circulares que se documenta exclusivamente en varias estelas del área meridional, halladas en los valles del Guadiana y del Guadalquivir, de estilo esquemático y con mayor número de objetos de origen foráneo. Estos hoyos se caracterizan por estar aislados y separados entre sí por distancias regulares, y se gravaban en la zona marginal de la composición, o junto al guerrero y que siempre son cinco (estelas de Zarza Capilla, Esparragosa de Lares I y II, Cabeza del Buey III, Benquerencia de la Serena, Alamillos y Olivenza); colocados en uno de los extremos del soporte y junto al guerrero (Navalvillar de Pela, el Viso II, Magacela, Écija III y Pedro Abad); y dispersos en nombre de 7 en la estela de Fuentedecantos. Estos huecos son dobles en las estelas de Pedro Abad y Espárragosa de Lares II, asociados a los personajes, y tres veces en la estela de Olivenza, coincidiendo con diferentes escenas representadas siempre aparecen en número de cinco y siempre en segundo plano. S. Celestino interpreta estos hoyos como la representación de algún sistema de medidas de peso, como los atesti-

${ }^{31}$ J. M. Blázquez, Algunos mitos y ritos orientalizantes traidos por los fenicios a Occidente. Monografías Eridú 1 , 2001, 205-226. guados en Cancho Roano, donde se documentan tres sistemas ponderales distintos, compuestos por cinco piezas de bronce que comenzarían a funcionar en torno al siglo vi. Estos ponderales han aparecido también en el Cortijo de Évora. Se conservan en colecciones particulares y en museos andaluces y levantinos, en Río Tinto, en torno al 700 a.C. y en Monte do Trigo, en la Beira alta portuguesa, de forma de tortas redondas. Ya A. Blanco, hace muchos años, me indicó que una torta redonda metálica de la Colección Calzadilla de Badajoz era, muy probablemente, un ponderal. Todos se fechan a finales de la Edad del Bronce.

Este sistema está documentado en el metal en el periodo premonetal de Ibiza. Estos sistemas, según S. Celestino, aparecen en las estelas de mayor grado de esquematización, que se fechan en los finales del siglo viII y a los principios del siglo vil a.C., ya en época del comercio fenicio y podrían aludir al control de ciertos productos comerciales de valor que intercambiaban con los comerciantes del sur. Estos productos serían de gran valor y exigirían una gran exactitud en el peso, quizá oro nativo, según nuestra hipótesis, pero no productos alimenticios.

Este sistema, en opinión de S. Celestino, lo cual es muy probable, indicaría en los primeros momentos del período orientalizante, unas relaciones comerciales con el mundo fenicio, pero su uso demostraría un conocimiento y la continuidad de un sistema de intercambios basado en normas de mercado ya empleado el Bronce Final.

S. Celestino sugiere otra gran novedad, cuál es la presencia de maestros de obra y de artesanos, de mujeres y de mano de obra en régimen de esclavitud o libre. Esta hipótesis la encontramos muy acertada. Ya se indicó que Pozo Moro sólo puede deberse a artesanos fenicios.

\section{CAMBIOS EN LA ESTRUCTURA SOCIAL DEL INTERIOR PENINSULAR}

A finales del siglo VII y comienzos del siglo VI se atestigua en el interior un cambio estructural de cierta importancia ${ }^{32}$. La necrópolis de Medellín, que coincide con esta fecha es de clara raigambre oriental en los ritos funerarios. Se observa en ella una gran homogeneidad social. La estructura es del tipo del suroeste fenicio.

${ }^{32}$ A. Rodríguez Díaz, J. J. Enríquez Navascués, Extremadura Tartésica. Arqueología de un proceso periférico, Barcelona, 2001. Sobre los fenicios en la costa atlántica portuguesa: A. M. Arruda, O comércio fenicio no territorio actualmente português, I. Coloquio del CEFYP, 59-77. 

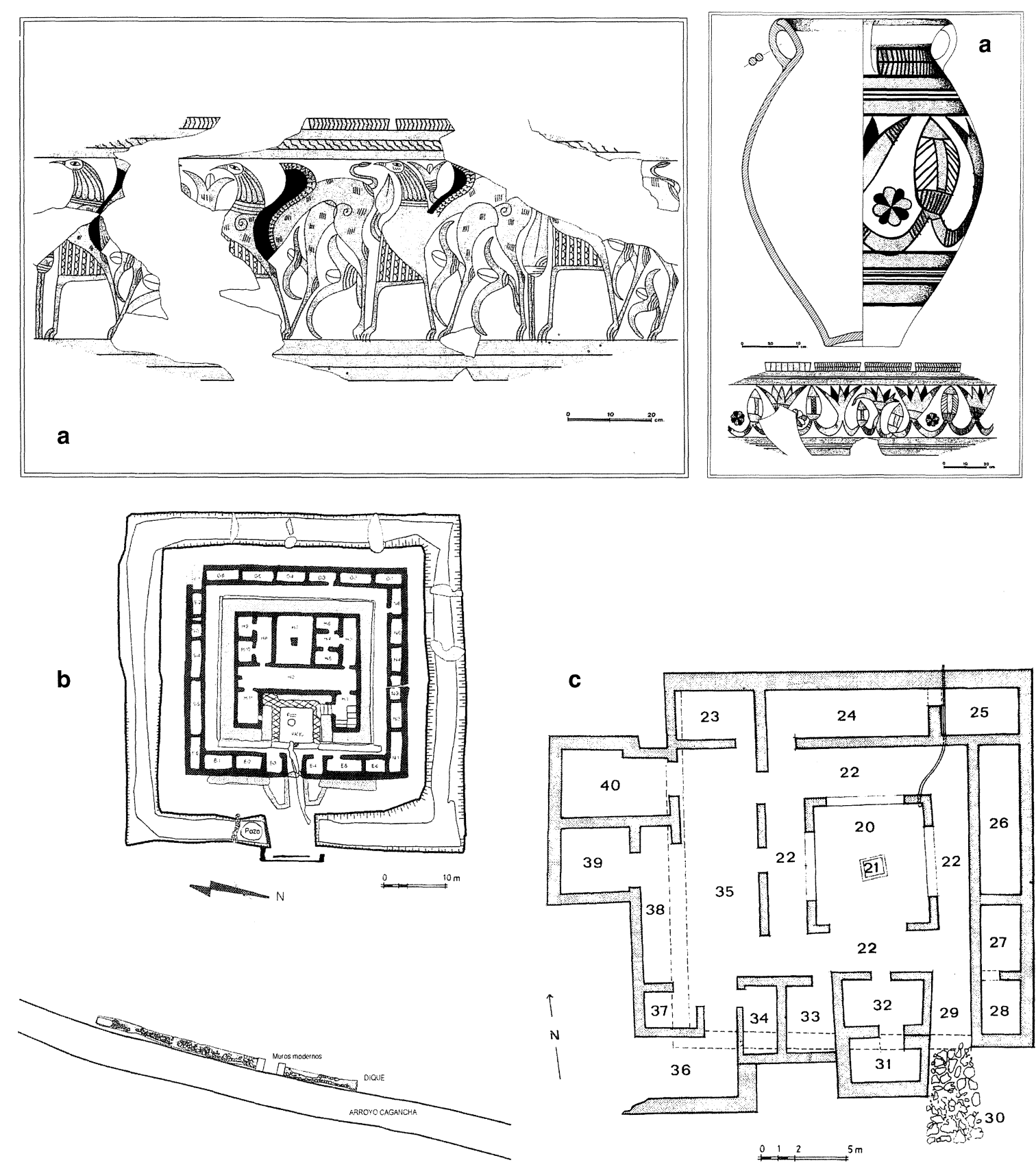

Fig. 2a. Decoración de dos pithoi de Carmona, Sevilla, según M. Belén; b. Santuario de Cancho Roano, Badajoz, según S. Celestino; c. Santuario de Abul, Portugal, según M. Mayer y C. Tavares de Silva.

A partir del siglo vi a.C., en los últimos momentos del Periodo Orientalizante, no son las estelas del Bronce Final, sino los edificios, como el último de Cancho Roano los que señalan las pautas para desentrañar la estructura económica y social del interior. Estos complejos tipo Cancho Roano (fig. 2b) se documentan en otros lugares, como en La Mata de Campanario, El Turuñuelo de Menda, en la cuenca media del Guadalquivir, en la Alta Andalucía y llegan hasta el periodo postorientalizante, cuando con la crisis del mundo tartésico se alteró el panorama. El edificio más parecido al de Cancho Roano es el de Abul en Portugal, tanto en la planta como en su cometido. Era también fenicio (fig. 2c). 
Hay dos templos superpuestos, uno datado en el siglo vII, el superior en el siguiente, también con suelo rojizo. Tiene razón $\mathrm{S}$. Celestino cuando sugiere que Cancho Roano es el único lugar donde podían actuar los mecanismos de poder y control necesarios para estructurar la sociedad. Este lugar tenía que ser, muy posiblemente, un lugar religioso, que al mismo tiempo fuera político, lo que sería el edificio $\mathrm{A}$, fechado en el siglo $\mathrm{v}$ a.C. Cancho Roano B se data en la segunda mitad del siglo vi y el $\mathrm{C}$ en el siglo vir a.C. Estos dos edificios son de carácter sagrado, pero también, como insinúa $\mathrm{S}$. Celestino, funcionaban como mercados. La técnica arquitectónica de estos dos edificios, lleva al área meridional, como a construcciones de Coria del Río o Montemolín, con paredes de adobe enlucidas, suelos rojos, altares en forma de piel de toro, etc. Estamos totalmente de acuerdo con la tesis de S. Celestino, que todos estos edificios son fenicios. Falta en Cancho Roano material arqueológico suficiente, pero el hallado, escaso, avala esta hipótesis. Sin embargo, el emplazamiento era indígena, como lo prueba la presencia de una cabaña de tendencia oval, fechada en el siglo vII a.C.

S. Celestino ha relacionado algunas estelas con determinados conjuntos arquitectónicos de carácter cultual en Carmona, Monte Molín, La Mata o Cancho Roano, lo que vincula las estelas con estos lugares. La base económica de todos estos emplazamientos del interior es la explotación agropecuaria, que arranca del Bronce Final, que sería la de otros asentamientos del periodo orientalizante del sur de Portugal, como Corvo I, Naves II, con suelo de arcilla roja, típico de los asentamientos fenicios, Farnão Vaz, o del sur de la Meseta, como Alarcos. En estas zonas se cambió la estrategia comercial. En el siglo vi a.C., esta zona periférica debió asumir el control de sus propios excedentes agropecuarios y reorganizar sus contactos comerciales, que comercialmente se dirigían hacia el sureste.

\section{CARROS, ESCUDOS Y ESPEJOS EN LAS ESTE- LAS: SU SIGNIFICADO}

Es posible matizar algunos aspectos de los carros aparecidos en las estelas ${ }^{33}$. Poseen carros 21 estelas (fig. 3), o sea, el 30\% del total. Destaca su ausencia en la Sierra de Gata y sus estribaciones, lo que re-

${ }^{33} \mathrm{~S}$. Celestino, Estelas de guerrero y estelas diademadas. La precolonización y la formación del mundo tartésico, Barcelona, 2001, 211-232. J. M. Blázquez, Fenicios y cartagineses en Occidente (cit. n. 1), 137-182. M. C. Fernández Castro, op. cit., 271-299. velaría la mayor antigüedad de las estelas de esta zona. El valle medio del Tajo, así como las sierras paralelas al río, han proporcionado 6 estelas con carro entre 20 catalogadas, lo que significa el $30 \%$ del total. El carro se introdujo en esta zona sin modificación sensible. El carro aparece como un añadido en la parte inferior de las lápidas en Alcántara I y II y Torrejón el Rubio I, y adquiere mayor relevancia en las estelas de Solana de Cabañas, Zarza de Montánchez y Las Herencias I. Ahora el guerrero se representa junto al carro. La generalización del carro se observa en los valles del Guadiana y del Zújar, donde aparece en 10 estelas de las 30 con guerrero, o sea, un $33 \%$ del total. En el valle del Guadalquivir el carro se representa en 3 estelas entre 15. En regiones periféricas sólo se documenta carros en las estelas de Fuente de Cantos y de Capote.

El origen morfológico otra los carros representados en las estelas hispanas lo encuentra S. Celestino en el mundo micénico, y no en el período geométrico griego. Coincidimos con la tesis de S. Celestino, de que los carros de las estelas hispanas no son de origen atlántico o centroeuropeo. Después del exhaustivo estudio sobre los carros de F. Quesada ${ }^{34}$ no se puede dudar que proceden del Oriente y que los trajeron al Occidente los fenicios.

El carro de cuatro ruedas de la Ría de Huelva es un carro fenicio del siglo vir a.C., como lo indican los cuatro prótomos de león, que decoran el carro, que se repiten en un carro depositado en la tumba 79 de Salamina de Chipre, fechado en el siglo viII a.C. ${ }^{35}$, aquí son 6 , y en un jarro de estilo Bicroma IV, con prótomo de león en el lado posterior del carro ${ }^{36}$. Piensa S. Celestino que los carros representados en las estelas no son de guerra, ni de transporte, tampoco servían para transportar el cadáver, si no que hay que ponerlos en relación con la creencia en un viaje al más allá.

Encontramos muy dudosa esta creencia en un viaje en carro al más allá, en la que no creyeron los fenicios, y los griegos en la fecha asignada a las estelas hispanas. Los etruscos admitieron un viaje a la ultratumba en carro o a caballo, pero en fechas pos-

\footnotetext{
${ }^{34}$ Datos para una filiación egea de los carros grabados en las «estelas del suroeste», Congreso internacional de Estelas Funerarias. Actas, Soria, 1994, 179-187. J. M. Blázquez, Fenicios, griegos y cartagineses en Occidente (cit. n. 1), 110136. La caja de carro de Mérida, en bronce, sigue prototipos chipriotas (J. M. Blázquez, Bronces de la Mérida prerromana. A. Blanco (coord.) Augusta Emerita. Actas del bimilenario de Mérida, Madrid, 1978, 11-14, láms. I-II, VI-VIII.

${ }^{35}$ V. Karageorghis, Salamis in Cyprus. Homeric, Helenistic and Roman, London, 1969, figs. 37-39.

${ }^{36}$ V. Karageorghis, J. des Gagniers, La cerámique chipriote de style figuré. Age du fer (1050-500 a.J.-C.), Roma, 1974, 30 .
} 

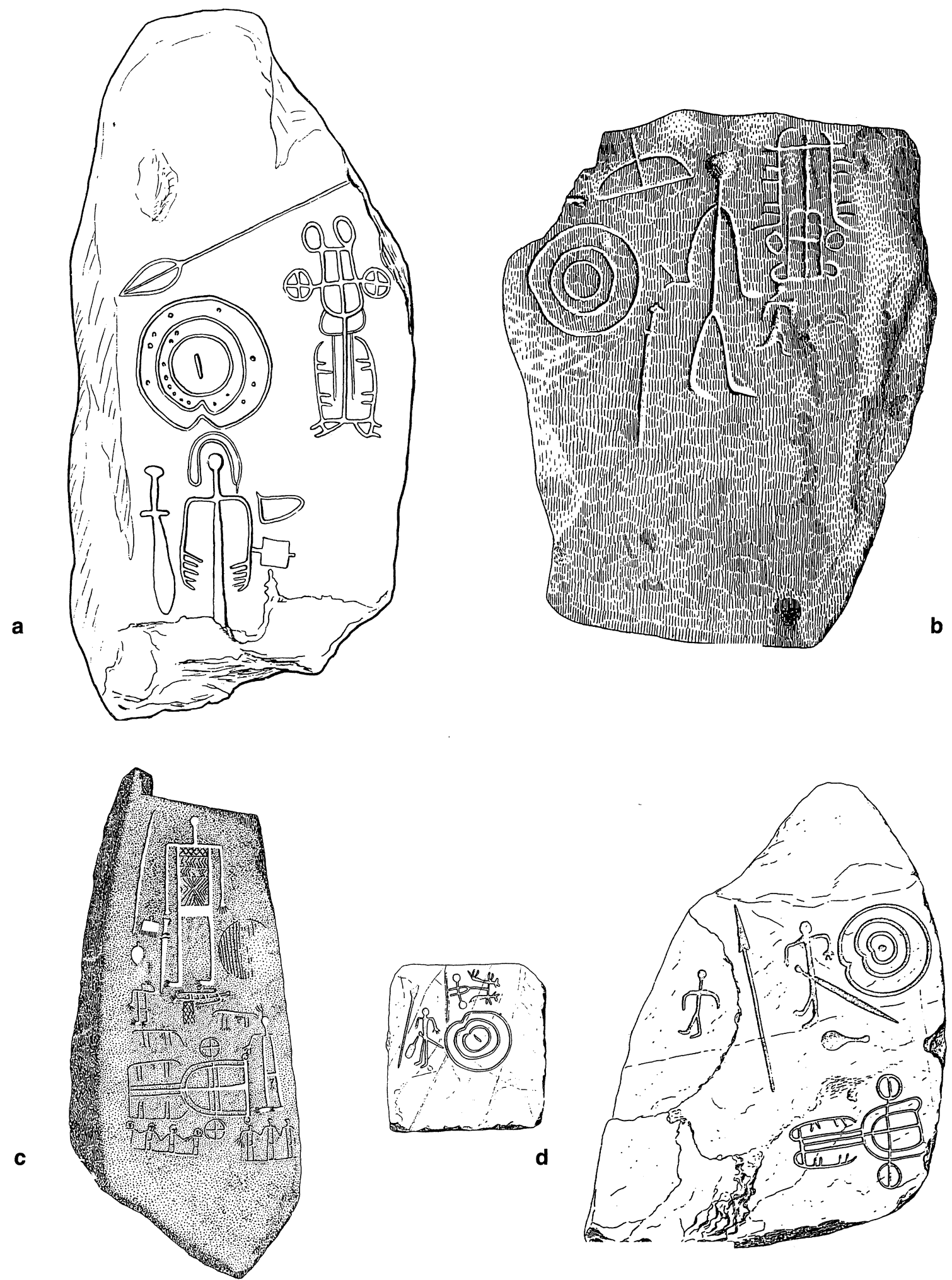

Fig. 3. Estelas: a. Cabeza de Buey I, Badajoz; b. Cortijo de Cuatro Casas, Carmona (Sevilla); c. Ategua, Córdoba; d. San Martinho II, Castelo Branco (Beira Baixa), según M. C. Fernández Castro. 
teriores ${ }^{37}$. Más probable es pensar que el sentido de los carros representados en las estelas es de puro prestigio y quizá no representaban la realidad. Este sentido deben tener muchos carros etruscos, como el de Monteleone de Espoleto, siglo vi a.C., lujosamente decorado ${ }^{38}$. Según F. Quesada las estelas con carro se fechan en el siglo viII y a comienzos del siglo vil a.C.; no se conoce el rito funerario de estas estelas, que muy posible es la cremación de los cadáveres. Siempre están tirados por dos caballos, no por toros o por bueyes. Este autor defiende, contra la tesis sustentada por nosotros, que los detalles tipológicos de estos carros no coinciden con el modelo del Próximo Oriente, de Chipre o del Sahara, sino con los ejemplares del Egeo. Estos carros no deben considerarse aislados, sino dentro del complejo de objetos que los acompañan e indican que poseerían un carácter aristocrático, lo que es muy probable, y, posiblemente, funerario.

Los objetos globalmente llevan, más bien, al ámbito mediterráneo y al Egeo, particularmente, en lo que hoy estamos de acuerdo, como la estela de Ategua. Coincidimos totalmente con la tesis de F. Quesada que no hay huellas de un sistema palacial en el suroeste hispano entre los siglos XI-VIII a.C., que mantuvieran arsenales de carros de guerra, almacenes de reparación, escuderías o escuadras preparadas, ni una infraestructura que permita hablar de un carro de guerra, ni para combatir desde él, ni para llevar al guerrero al campo de batalla. Los carros de las estelas responden a verdaderos carros de prestigio traídos por comerciantes orientales. En ambas tesis estamos totalmente de acuerdo. No son exclusivamente militares; probablemente fueron ceremoniales, al igual que los carros etruscos de Capua, de Vulci, de la necrópolis de Ostería, de Populonia, de Castel San Mariano y otros. Comienzan a adquirir un significado como carros del tránsito a la ultratumba, lo que creemos más defendible, en fecha posterior.

Estas influencias quedan más patentes en algunos otros elementos de las estelas, como son los es-

${ }^{37}$ J. M. Blázquez, Imagen y mito (cit. n. 15), 114-158. Sobre el papel funerario del caballo véase 42-68. F. de Ruyt, Charum démon étrusque de la mort, Bruxelles, 1994. D.C. Kurtz, J. Boardman, Greek Burial Customs, London, 1971. E. Vermeule, Aspects of Death in Early Greek Art and Poetry, Berkeley, 1979.

${ }_{38}$ A. Emiliozzi (coord.), Carri da guerra e principi etruschi, Milano, 2000. En Etruria carros con difuntos están representados en la Pietra Zannoni de finales del s. vil a.C., precedido el difunto de un auriga (fig. 7), en las estelas de C. Polisportivo de Bolonia, de la segunda mitad del siglo v a.C., con viaje del difunto a la ultratumba acompañado de un de monio alado (41, fig. 11); de Asterope Augerio con demonio alado sobre el carro (50, fig. 3$)$, de la segunda mitad del s. Iv a.C., etc. cudos de escotadura en V (fig. 4), que se documentan en 39 ejemplares de un total de 67 . Hemos defendido el origen oriental y más concretamente fenicio de estos escudos, siguiendo las tesis de Dunbabin, 1957 y de Gräslund, 1967. Llegarían al Occidente como productos del comercio en el siglo VII, fecha que levantaríamos hoy hasta el siglo viII. El escudo del Monte Ida de Creta es obra de artesanos fenicios según Dunbabin. Los cascos o cuernos en forma a de $\mathrm{U}$ o de $\mathrm{V}$ de lira, es otro elemento importante a tener en cuenta. En la región del ZújarGuadiana es donde se documenta mayor número (Magacela, Esparragosa de Lares I, El Viso I y II, Valdetorres I y Alamillo). En el valle del Guadalquivir aparecen en Écija I y II. Estos cascos, muy probablemente, son de origen mediterráneo y serían hermanos de los que llevan los guerreros de Cerdeña, traídos por los fenicios y fechados en los siglos VIII-VII a.C., contemporáneos por lo tanto, de los cascos con cuernos de las estelas ${ }^{39}$.

${ }^{39}$ E. Anati (dir.), I Sardi della Sardegna dal Paleolitico all'età romana, Milano, 1985, passim, figs. 116-118, 120 121. E. Acquaro, Miniere e Metalurgia nella Sardegna fenicia e punica, I. Coloquio del CEFYP, 93-108. El autor recoge la teoría de Sandro Fillippo Bondi sobre Cerdeña: «El aprovisionamiento de metales de parte de los fenicios no se fundamenta en la fase precolonial sobre un control directo de las fuentes de producción, sino que pasa a través de la instauración de relaciones de asociación con los grupos nurágicos, que tenían el control. Los bronces, los trípodes y los candelabros encontrados en contextos nurágicos de los ss. IX-VI a.C., no deben ser interpretados como la contrapartida fenicia para adquirir metales sino, posiblemente, como materiales que sugieren la inclusión de los participantes del mismo circuito y la pertenencia al mismo nivel de estatus social; testimoniando en esta región el progresivo emerger de las iniciativas ligadas a mercaderes de profesión, exponentes ellos mismos de las aristocracias ciudadanas a juzgar por el valor ideológico de los más antiguos materiales importados en la isla». Estas ideas son perfectamente aplicables al Occidente. P. Bartoloni, La Sardegna croceria del Comercio fenicio, 105-108. Defiende el investigador italiano que existe una ruta abierta al menos desde finales del s. XIV, hasta la mitad del s. viII, que es diversa a la existente desde la mitad del s. VIII hasta la mitad del s. VII. Fntre los siglos XII y la primera mitad del siglo IX participaban en estas empresas los mercaderes de la costa siria septentrional, Al-Mina, Ras el Basit, Ras Ibn Hane o Tel Sukas, a los que hay que añadir gentes de Ashadod, de Ashkadon, o de Shekedesh. Estos son los que participan en el periodo precolonial y creemos que participaron en Occidente como resultado de la gran dispersión de los Pueblos del Mar, que debieron llegar al Occidente. Las etapas sucesivas de esta viaje eran Tarso y Rodas, la costa meridional de Creta, los numerosos recipientes de origen nurágico, datables entre los ss. XII y viII a.C., Cithera con su templo de Ashtart, Ashkalon, la costa del Peloponeso a través del canal de Otranto, la costa de Calabria y el estrecho de Mesina. Esta ruta fue cerrada a la navegación fenicia en la segunda mitad del s. vill por la fundación de Zancle y de Region. Cerdeña, visitada por los micénicos, se convirtió en un punto estratégico hacia Tartessos. Sant' Inuberina, próxima a las minas de plata, fue el primer asentamiento nurágico de los mercaderes orientales con ánforas fenicicias, frecuen- 
a
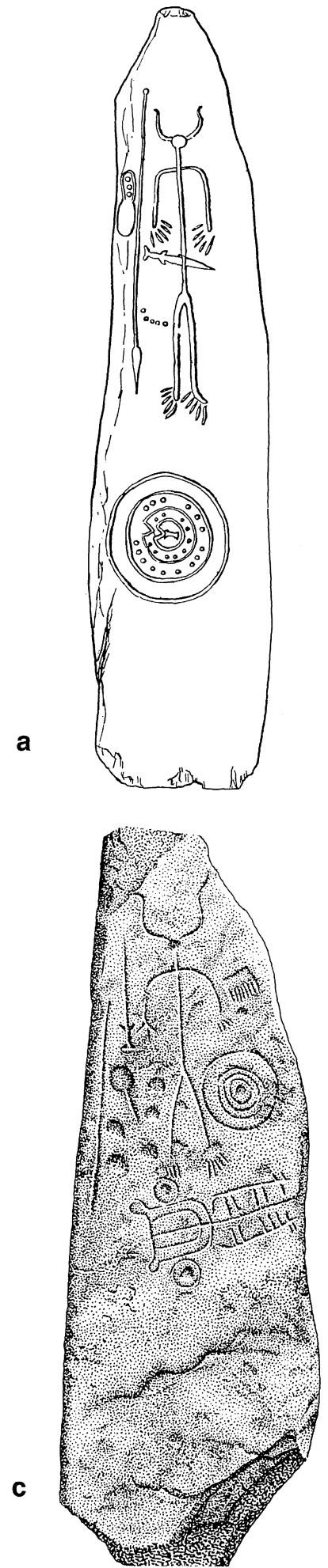

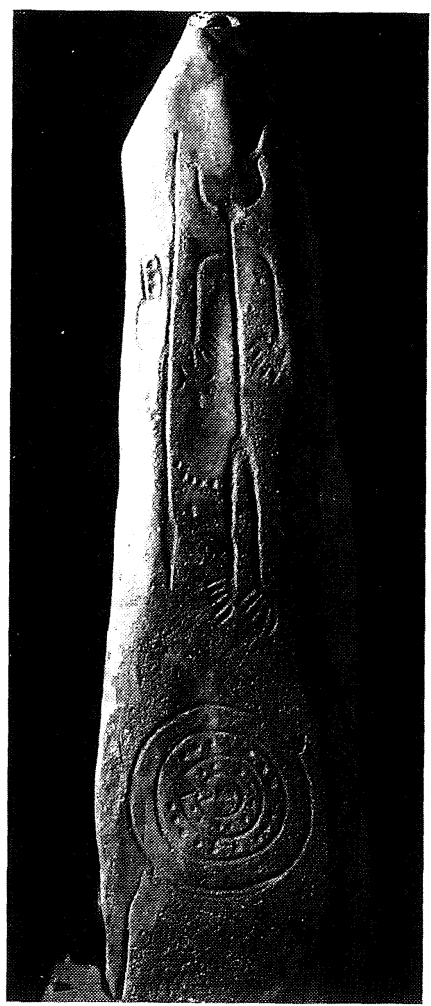

b

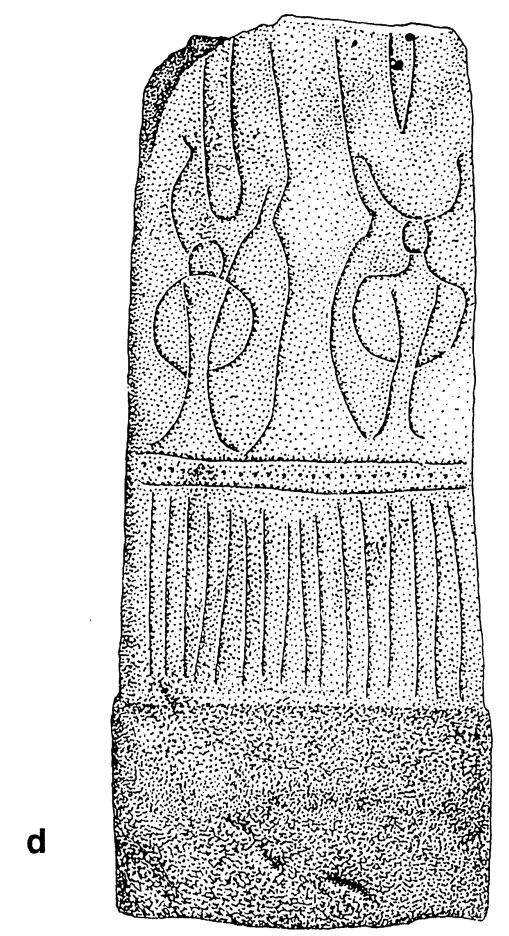

Fig: 4. Estelas: a. Magacela, Badajoz; b. Magacela; c. Fuentes de Canto, Badajoz; d. San Martinho I, Castelo Branco (Beira Baixa), según M. C. Fernández Castro. 
Los espejos representados en las estelas completan este panorama. Un ejemplo aparece en San Martín de Trebejo. En la región de Zújar-Guadiana, 9 estelas de 20 llevan espejo, y en el valle del Guadalquivir, 6 de 13. Somos de la opinión que son de procedencia mediterránea, como indica S. Celestino. Son frecuentes en necrópolis micénicas. Aparecen en Palaepafos, en Pantálica y en Casibile. En la sepultura de la Aliseda se recogió un espejo junto a joyas de cinturón y pendientes, jarro tallado en cristal de roca, fabricado en el norte de Siria, de declara procedencia fenicia, como parece indicarlo que en un relieve funerario de Marash de estilo neohitita reciente, tratado a finales del siglo vIII, se represente la hija con espejo en la mano entre sus padres. La escena posee un claro sentido funerario. Los alimentos en manos del difunto o sobre la mesa simbolizan la comida funeraria en la ultratumba. La espiga, que sostiene el difunto, en su mano izquierda, es claro símbolo de la naturaleza, o quizá de la inmortalidad del hombre. Madre e hija sostienen en sus manos dos husos, y la hija un espejo ${ }^{40}$.

En este relieve el espejo tiene, probablemente, carácter funerario al igual que en las estelas. No es un objeto de lujo, por eso se deposita en las tumbas. En una segunda estela con esposos, de la misma localidad, databa a finales del siglo vill o a los comienzos del siguiente, la dama sostiene un espejo y el varón un racimo de uvas ${ }^{41}$. El gesto triste de los esposos indica bien a las claras que se trata de dos difuntos. El racimo de uvas aludía a la profesión del hombre.

\section{CRÍTICA DE LAS IDEAS DE LA PRECOLONI- ZACIÓN Y LA COLONIZACIÓN FENICIA}

C. G. Wagner ${ }^{42}$ matiza el carácter del comercio precolonial, que llama comercio lejano en lugar de precolonización. Tiro, antes del siglo x y hasta Ezequiel, que comenzó su ministerio profético en el año

tado desde la primera mitad del siglo vilI. Antas mantenía contactos comerciales entre los ss. X y IX a.C. La costa más frecuentada fue la que contenía minerales, que era el primer objetivo de los fenicios. Los territorios de Sulcis y Sinis indican que, al igual que en Occidente, los fenicios tenían intereses agrícolas. Hacia la mitad del s. viII Cerdeña fue un nudo de comunicaciones importante entre el norte de África, Etruria y Occidente. En el s. Ix, la acción fenicia fue eminentemente comercial y a partir del s. viII colonial. Lo mismo debió suceder en Occidente.

${ }^{40}$ E. Akurgal, Orient et Occident. La naisance de l'art grec, París, 1969, 133, lám. 28.

${ }^{41}$ E. Akurgal, op. cit., 132, lám. 26.

${ }^{42}$ Comercio lejano, colonización e intercambio desigual en la expansión fenicia arcaica por el Mediterráneo. I. Coloquio del CEFYP, 79-91.
593 a.C., y actuó hasta el 571 a.C., no creemos que el Occidente se los proporcionase, necesitaba alimentos, dato verdaderamente importante para explicar las razones de los orígenes de la colonización fenicia en Occidente.

No existía en este periodo relación causal entre circulación de productos y economía de mercado, lo que es exacto. Comenta este autor el interés que se concede generalmente al palacio o templo en el abastecimiento de productos exóticos, dejando los beneficios mercantiles a un hipotético sector privado que se considera profesional. Tesis que disiente, acertadamente, ya que no se puede hablar de mercado con Asiria, o de los metales o de los productos manufacturados, que proporcionaban los fenicios, sirios e israelitas, que eran productos de saqueo. Es totalmente acertada la tesis de C. G. Wagner de que la economía fenicia en sus relaciones con los indígenas, obedecía a las necesidades de la élite.

La colonización originó una temprana actividad urbana, un poblamiento de cierta densidad y una actividad económica diversificada, lo que fue cierto. Puntualiza el autor que la colonización fenicia en Occidente se ha fechado en torno a mediados del siglo viII, fecha que el autor levanta al menos 75 años, basado en los análisis de $\mathrm{C} 14$, lo que juzgamos muy exacto. Con Tartessos el comercio fenicio de metales jugó un papel importante, lo que creemos probable, pero es un comercio basado en intercambios desiguales. Los fenicios obtienen grandes cantidades de metales a cambio de mercancías. Esta tesis, que es con seguridad cierta se apoya en textos como el de Diodoro (V.35.4-5), partiendo de Posidonio, o mejor de Timeo o del Pseudo Aristóteles (Mir. 135) y de Estrabón (III.5.11), autores todos citados por C.G. Wagner, quien explica acertadamente la expansión hacia Occidente como una estrategia muy bien definida y compleja, cuyas causas deben buscarse en la situación interior de las ciudades fenicias. La precolonización no implica control ni reivindicación de espacio geográfico alguno. La expansión fenicia comienza con la conquista simbólica de los límites del mundo, manifestada en llegar a las Columnas de Melqart (Str. III.5.5; Mel. III.6.46).

Los primeros asentamientos fenicios en Occidente, según este autor, datarían de mediados de la segunda mitad del s. Ix, lo que creemos muy posible; seguramente se pueden remontar al siglo $\mathrm{x}$, así como que las expediciones, que llegaron a las columnas de Melqart, se fecharían en la época de Hiram de Tiro. El texto citado de Estrabón, que habla de los tres intentos de fundación de la ciudad, confirma la tesis de C. G. Wagner, que expresa una vo- 
luntad de asociar estos establecimientos occidentales a Tiro, a su templo y a su rey. El texto de Estrabón menciona cuatro veces a Melqart. Los navegantes fenicios en estos tanteos tenían la certeza de que eran los confines de la tierra habitada y el término de las empresas de Melqart.

C. G. Wagner insiste en la importancia del palacio en las empresas comerciales, lo que creemos ser totalmente cierto, e incluso califica a Gadir, en origen, de dependencia del palacio de Tiro, lo que debió ser cierto. A la larga, el intercambio desigual terminó desarticulando las sociedades indígenas.

\section{LAS ETAPAS DE LA PRECOLONIZACIÓN}

La tesis de una etapa precolonial a la colonización fenicia, se admite hoy generalmente, entre los investigadores, como V.M. Guerrero ${ }^{43}$. M. Almagro ${ }^{44}$, acepta igualmente una precolonización oriental, que explicaría las primeras navegaciones fenicias hasta Occidente y el Atlántico, siguiendo las rutas descubiertas en tiempos de los Pueblos del Mar, en lo que estamos totalmente de acuerdo. Estos elementos precoloniales son de diferentes tipos: objetos de cultura material, innovaciones tecnológicas, sociales e ideológicas, armas de prestigio, ajuar de banquetes y nuevos ritos funerarios, que evidencian la existencia de una élite. Los primeros elementos orientales se fechan en el siglo XII a.C., como las hachas de enmangue directo de Muros y de las Losas del Alentejo; las azuelas de apéndice antiguo asociadas en Osuna, a un hacha de tipo Rosnoën, fechadas en el Bronce Final I y II; las puntas de lanza de bordes sinuosos, las cuchillas de bronce semejantes a las del Micénico Último III. Estos objetos proceden del Mediterráneo Oriental. Se documentan, también, contactos con Cerdeña y con Sicilia. A estos objetos continúan otros de origen chiprio-sirio-fenicio, de la fase siguiente, ya de finales del II milenio y de comienzos del I, como elementos de banquete, posteriores al cambio de milenio; vasos de tipo Berzocana; asadores de tipo Amatunte; ganchos de carne de tipo Solobeira, semejantes al was egipcio del III milenio. Las hoces de tubo pueden tener un origen chipriota $y$, probablemente, la metalurgia de la plata y la introducción del hierro, en relación con el desarrollo minero-metalúrgico de finales de la Edad del Bronce, de origen chiprio-oriental. Los más antiguos escudos con escotadura en $\mathrm{V}$, los fecha

${ }^{43}$ Intercambios y comercio precoloniales en las Baleares (c. 1100-600 B.C,), I. Coloquio del CEFYP, 35-53.

${ }^{44}$ La precolonización fenicia en la Península Ibérica, Actas II, op. cit. (n. 16), 711-721. este autor en el siglo $\mathrm{x}$, anteriores, aparentemente, al hallazgo de la Ría de Huelva, datado en este siglo. Se observa un nuevo incremento de contactos con Oriente sin solución de continuidad con la fase precedente. A esta etapa pertenecerían la generalización de la fíbula de codo agallonada, tipo Huelva; la mayor parte de los escudos con escotadura en $\mathrm{V}$, y el carro. Un casco de la Ría de Huelva tiene parelelos en otro de Enkomi. El depósito de Señora da Guia, con vasos de bronce, instrumentos de cocina y carros rituales de origen sirio-chipriota debe fecharse en torno al siglo viII a.C.

Estos contactos Oriente-Occidente siguen las mismas vías abiertas por los Pueblos del Mar. Este ambiente precolonial, a partir del 1000 , puede considerarse fenicio y continúa hasta la etapa colonial fenicia. Estos últimos elementos reflejan una koiné cultural sirio-palestina-chipriota heredera del mundo postmicénico y de los Pueblos del Mar.

El trabajo de M. Almagro-Gorbea es de gran importancia por proporcionar base arqueológica a la teoría de la precolonización, y en distinguir sus dos etapas.

Uno de los descubrimientos más importantes en el ámbito fenicio de Occidente, en los últimos años, es la colonia fenicia de La Fonteta ${ }^{45}$, Guardamar del Segura (Alicante), fechada en los siglos viII-VI a.C., con muralla de triple cuerpo, con bastiones de unos $15 \mathrm{~m}$ de altura y un antemuro de adobes. Desde el comienzo la colonia se dedicó a la metalurgia, como lo indican los hornos y los escoriales (cobre, plata, hierro), sobre la plataforma de la playa del siglo vIII. Debió de existir un santuario urbano, una necrópolis y un tofet, según se desprende de las molduras arquitectónicas y de las numerosos estelas. Las cerámicas proceden de Fenicia, Cartago, Sulcis y griegas, que prueban un intenso comercio con el exterior.

Los barcos que utilizaban los fenicios en sus viajes al Occidente serían del tipo del barco votivo de Caergwrle ${ }^{46}$ que parece ser el representado cargado de mercancías en el relieve del British Museum de época de Senaquerib, y no las naves de transportar madera representadas en relieves de Sargón II (721705) ${ }^{47}$ y en las puertas citadas de Balawat partiendo de Tiro. Podían ser también los representados en el gran templo de Kition ${ }^{48}$ fechado en el siglo Ix.

${ }^{45}$ A. González Prats, E. Ruiz, El yacimiento fenicio de La Fonteta (Guardamar de Segura, Alicante, Comunidad Valenciana), Valencia, 2000.

${ }^{46}$ J. M. Blázquez, Tartesos y los orígenes de la colonización fenicia en Occidente, lám XC.

47 J. B. Pritchard, op. cit. (n. 23), 262, figs. 107-108.

${ }^{48}$ V. Karageorghis, Kition (n. 13), 99, lám. 73. 


\section{LOS ORÍGENES DE TARTESSOS}

Entre las teorías recientes sobre Tartessos destaca la de D. Ruiz Mata ${ }^{49}$ que es un excelente conocedor del tema de los orígenes de la colonización fenicia en Occidente. Acaba de publicar una síntesis sobre Tartessos que es muy importante por el profundo conocimiento que tiene el autor de la Andalucía Occidental, debido a las numerosas campañas de excavaciones que ha realizado. D. Ruiz Mata se plantea repensar el concepto histórico de Tartessos. Tan sólo nos detendremos en algunas opiniones que son de particular importancia. Da especial importancia a la opinión de M. Bendala sobre los orígenes de Tartessos. Según este autor, Tartessos se sitúa después de la caída del mundo micénico. Llegarían entonces inmigrantes de la diáspora de los Pueblos del Mar, a finales del II Milenio, de variado carácter étnico y cultural, pero de componente fundamentalmente griego y no fenicio, lo que parece ser probable. La presencia de estos inmigrantes cambió la sociedad indígena.. Serían dirigidos por una casta militar que buscaba nuevas fuentes de riqueza. Seguían viejos caminos ya conocidos, lo que es posible. Se incorporarían fácilmente a la población autóctona gracias a la superioridad militar y se convertirían en la casta dominante reflejada en la estelas. D. Ruiz Mata es contrario a la tesis de la precolonización semita en Occidente, que «no deja de ser un concepto abstracto y forzado por la contingencia de las fuentes, el voluntarismo de determinados autores y la existencia de la ciudad y reino de Tartessos». Señala el autor, que de esta época se conocen pocos yacimientos y ninguna ha sido excavado en extensión. Poco se puede decir de su estructura social y económica. Lo poco que se conoce apunta a la existencia de una monarquía y de un imperio de Tartessos, se deduce del estudio de los materiales la continuidad cultural sin cambios ni rupturas. El periodo comprendido entre los siglos XIII y XII a.C. se caracteriza por la llamada cerámica de Boquique, que perdura hasta el s. IX a.C. D. Duiz Mata caracteriza la cultura de la segunda mitad del II Milenio por una regresión demográfica en relación a la Edad de Cobre, por los escasos asentamientos y por un sistema urbano arcaico; por materiales poco elaborados en tipos y decoraciones y por enterramientos que sugieren una mas estructura social tribal que estatal. De la segunda mitad del segundo milenio a.C. se conocen enterramientos en Huelva (Andévalo), Sevilla (El Gandul) y Cádiz, con difuntos inhumados y ajuar modesto. La reali-

${ }^{49}$ En Protohistoria de la Península Ibérica (cit. n. 1), 1-190. dad no responde a las características, que han asignado algunos autores, a Tartessos, como ciudad, región, monarquía y estructuras socio-económicas complejas y jerarquizadas. De todos estos datos deduce D. Ruiz Mata que Tartessos no parece que fuera una entidad social preexistente a la llegada fenicia, lo que creemos ser totalmente cierto. El espacio en el que se desarrolló la cultura tartésica está ocupado por las actuales provincias de Cádiz, Huelva y Sevilla. A partir del s. IX a.C., se percibe un cambio sustancial en el territorio, en la cultura material y en los enterramientos. Tal es el panorama que encontraron los fenicios a su llegada a Occidente. Aumentan ahora los asentamientos y estos están jerarquizados. Su concentración se sitúa en la bahía de Cádiz. Se advierte la estructuración de un territorio político y jerarquizado. Los poblados se sitúan en elevaciones de escasa altura y carecen de murallas. La fase más antigua está representada por los poblados de Valencina de la Concepción, Huelva, S. Bartolomé, Camping, El Carambolo, etc. Algunos poblados se asientan en lugares elevados y de fácil defensa natural. A partir de comienzos del I Milenio aparece un patrón de asentamiento que responde a estas necesidades metalúrgicas, agrícolas y ganaderas y a la comercialización de productos, asentado en las márgenes de los ríos. Se pueblan las zonas mineras onubenses y se inician las actividades metalúrgicas.

De todo esto deduce D. Ruiz Mata la existencia de un núcleo cultural tartésico, en un paisaje básicamente llano, bien comunicado y rico en recursos económicos. El gran centro minero fue la sierra de Huelva, Quebrantahuesos, Tejada la Vieja y Cerro de la Matanza, y el Guadalquivir, granero.

Piensa D. Ruiz Mata, que no se puede hablar de una estructura urbana. La ornamentación bruñida es uno de los rasgos decorativos típicos del Bronce Final tartésico. Se introdujeron cambios sustanciales en las costumbres funerarias a partir del s. IX o comienzos del viII a.C.. Surge el enterramiento en túmulos y aparece el rito de la incineración en ustrina y después se cribaban los restos óseos. La economía de las gentes enterradas era fundamentalmente ganadera. Se advierte fuertes diferencias sociales. Las tumbas más ricas son de enterramientos de varones, como en la necrópolis de las Cumbres, con 62 enterramientos alrededor del ustrinum del túmulo $\mathrm{T}$, depositados en urnas, dentro de pequeñas fosas, excavadas en el suelo. El ajuar estaba compuesto por una placa de cinturón, una fíbula de doble resorte y un cuchillo de hueso. La urna cineraria es un vaso de cuello alto, cuerpo ovoide y fondo plano, con superficie bruñida. Características parecidas tienen los túmulos A y B de Setefilla. Las cámaras de estos 
túmulos indicarían la existencia de régulos locales independizados de la producción directa y de la concentración de la riqueza en estos jefes tribales. Se diferenciarían de la población incineradora. Los personajes enterrados en las cámaras poseen objetos de lujo e importados. La población debía estar agrupada en clanes y no debió existir un estamento militar. En las cumbres se han descubierto enterramientos colectivos con escasa diferencia entre ellos.

La economía de la población tartésica era agrícola, ganadera y metalúrgica. El fondo de cabaña de El Carambolo, lo fecha este autor en los ss. IX-VIII a.C.

En Setefilla, en los ss. IX-VIII a.C., se encontraban recuperadas las actividades metalúrgicas.

D. Ruiz Mata es partidario, lo que es un gran acierto, de analizar la colonización fenicia como un proceso de aculturación/interación. No antes del s. IX a.C., se documentan los primeros indicios fenicios en el Mediterráneo Oriental.

El Morro de Mezquitilla, que es el asentamiento más antiguo, se fecha en torno al 750 a.C.. Recoge el autor la opinión de P.M. Bikay, para quien la colonización occidental se data a finales del s. viII. El muro de sillares de Huelva se levantó en un ambiente cultural indígena, con escasos materiales cerámi$\cos$ a torno, lo que es una prueba de la primera presencia fenicia.

El fragmento de crátera del Geométrico Medio II, 800-760 a.C., debió llegar en barcos fenicios, como regalo o intercambio con las clases más elevadas.

Los primeros contactos entre fenicios e indígenas serían de ragalos. El contacto, al comienzo fue pacífico. Este proceso comenzó a principios del s. VIII, pariendo del Castillo de Doña Blanca.

Los indígenas, piensa este excavador, no llegaron a Tartessos, sino a una región intensamente habitada por indígenas del Bronce Final.

Los fenicios obtuvieron el instalarse en Occidente y la posibilidad de la explotación de la plata, la explotación agrícola del territorio y el monopolio del comercio exterior. Gadir llegó a ser un estado occidental.

El establecimiento de Cádiz se data en torno al 800 a.C

En la segunda mitad, o a finales del s. viII a.C., se obtuvieron cambios en las sociedades indígenas, debido, en parte, a la introducción de nuevas tecnologías. Se introdujo el hierro y técnicas para la fabricación de herramientas y de los productos resultantes. Se necesita ahora la fundición, la forja y el martilleo. Sin embargo, no era posible aún la fundición en molde. Desde el inicio una de las aportaciones más importante fue la metalurgia y el hierro. También aparece la copelación de la plata. No está claro si los fenicios controlaban los centros mineros. Una de las aportaciones más importantes, desde los fenicios del s. VII a.C., se dio en la toreútica y en la orfebrería, que materializan la tecnología de Tartessos, que necesitaba de artesanos cualificados.

El urbanismo y un régimen de jefatura surgió de la concentración de la población indígena, de la especialización y de la división del trabajo, de los intercambios y del comercio exterior.

Una ciudad fenicia de comienzos del s. viII es el Castillo de Doña Blanca, próxima a Gades, con un número de 225 a 250 viviendas y con fortificaciones precedidas de fosos.

Las minas de Río Tinto se explotaron con una técnica traída del Oriente del $\mathrm{x}$ a.C.

Algunos poblados, como San Bartolomé se dedicaron a la metalurgia de la plata. En el periodo orientalizante, la metalurgia fue una actividad fundamental, perfectamente organizada y canalizada a través de Gades y de Huelva. A partir de finales del s. viII a.C., y debido a los estímulos fenicios, comenzó el auge de Tejada la Vieja.

En la primera mitad del s. viII a.C., se detectaron las primeras importaciones fenicias. En el Cerro de Salomón, los primeros materiales se datan a finales del s. viII a.C. Los trabajos metalúrgicos en San Bartolomé comienzan en la segunda mitad del s. viII, al igual que en Tejada la Vieja.

En poblados como Morro de Mezquitilla, Toscanos, Castillo de Doña Blanca, se documenta la actividad fenicia.

La organización artesanal se encontraba muy especializada y debió haber una gran demanda de productos.

Para M. Bendala ${ }^{50}$ la cultura tartésica se desarrolló entre los comienzos del milenio y el s. vi a.C. la fase formativa abarca desde el comienzo del milenio al siglo viII a.C. M. Bendala concede mucha importancia a las estelas, que se debieron vincular con cerámicas pintadas con decoración geométrica, relacionadas con el periodo gecmétrico griego, Rodas o Chipre, y con la decoración bruñida conocida en el Próximo Oriente, en Cerdeña y en Samos, desde el 1000 a.C. Pellicer, Almagro y Bendala consideran las cerámicas pintadas tartésicas la versión local del geométrico griego. Su distribución delimitaría el área de acción de Tartessos desde sus etapas formativas. Barceló por el contrario, piensa que las estelas caen fuera del área tartésica, al no aparecer ni en Huelva, ni en Cádiz, ni en Sevilla. Las que han aparecido próximas al Guadalquivir pertenecerían a

${ }^{50}$ Tartesios, iberos y celtas. Pueblos, culturas y colonizadores de la Hispania Antigua, Madrid, 2000, 43-105. 
gentes llegadas de fuera. Llama la atención la profunda penetración interior, en la que se barrunta el afán por controlar tierras ricas desde el punto de la agricultura y de los metales, hipótesis que no hay que descartar. Señala M. Bendala que se suelen representar armas: escudos circulares, lanza y espada. Los carros representados los cree este autor carros de guerra, típicamente mediterráneos, y más concretamente egeos, propios de finales del segundo milenio o de comienzos del primero, lo que es muy probable como demostró F. Quesada. Piensa M. Bendala que ciertos detalles tienen un sentido más ritual que guerrero. Servirían como vehículo heroizado para el viaje al más allá, aunque nosotros hemos rechazado la idea de heroización, por estas fechas se rastrea en el Egeo y pudo venir con los carros. Las estelas reflejan un lenguaje conceptual y simbólico. La cultura material de la primera época de Tartessos sería una sociedad jerarquizada, cuyas capas superiores estarían representadas en estas estelas. La casta superior serían los guerreros. Las estelas demostrarían el privilegio y el poder de los dirigentes tartésicos.

En la segunda etapa orientalizante, debido al estímulo decisivo de los fenicios, las tumbas principales responden al mismo ritual. Del grupo dirigente debió brotar la forma de poder monárquico.

Los tartesios pronto dispusieron de una estructura organizativa capaz de obtener excedentes, que se podían comercializar a escala internacional, situación que aprovecharon los mercaderes fenicios, cuya presencia, según este autor, se detecta ya en el s. IX a.C. Los fenicios penetraron al interior formando colonias de comerciantes y artésanos, como en Carmona. O creando centros nuevos como Spal (Hispalis). Pronto debieron surgir conflictos entre tartésicos y fenicios.

\section{COLONIZACIÓN GRIEGA}

M. Blech ${ }^{51}$ ha apuntado algunas ideas importantes sobre la colonización griega.

Piensa este autor que el fragmento griego más antiguo citado pudo formar parte de un comercio euboico. Un comerciante fenicio pudo obtener la cratera ática en Al Mina o en Pithekoussai, Isquia.

En Occidente se distribuyeron las llamadas ánforas euboicas y áticas, que suponen unas relaciones regulares entre mercaderes griegos, primero euboicos y más tarde corintios y fenicios en el Mediterráneo central. Las primeras ánforas SOS fueron transportadas 23. desde finales del s. VIII a.C., en barcos euboicos y corintios hasta los puertos de Sicilia e Italia y, desde allí, en naves púnicas al Occidente (Toscanos y Torre del Mar en Málaga y Aljaraque en Huelva). Estas ánforas SOS transportarían aceite o vino. Con estas ánforas se importarían los dos esquifos euboicos de Huelva y los cotiles corintios de Almuñecar. El casco corintio, de principios del s. vII a.C., de Guadalete, debió ser un exvoto a algún dios fluvial.

A partir del 550 a.C., aproximadamente, descienden las importaciones griegas, principalmente del área greco-oriental y aumenta la cerámica ática, lo que parece indicar unas relaciones comerciales regulares. Los comerciantes griegos se afincaron en Huelva por lo menos desde el 600 al 500 a.C.

Todas estas teorías, a veces contradictorias, perfilan un panorama más exacto del estado del Occidente a finales de la Edad del Bronce y de la sociedad que encontraron los fenicios, así como de los orígenes del reino de Tartessos.

Una gran novedad reciente es la hipótesis de trabajo de A. Maderos y L. Ruiz Cabrero ${ }^{52}$, basados en una serie de grafitos sobre cerámicas fenicias halladas en el Cabezo de San Pedro, Puerto de Huelva, El Carambolo, Cerro Macareno, Peñanegra y Medellín con letras fenicias, lo que llevaría a pensar que la escritura tartésica del Occidente es de origen fenicio, como es lógico.

En los últimos años, la investigación española y portuguesa ha dado un gran avance en el conocimiento de la protocolonización y colonización fenicia en Occidente, presentándose hipótesis de trabajo de gran novedad, que cambian totalmente el panorama.

\section{ADDENDA}

D. Ruiz Mata (La fundación de Gadir y el Castillo de Doña Blanca; contrastación textual y Arqueología, Complutum 10, 1999, 279-312) defiende que la primitiva Cádiz, a comienzo del s. vIII a.C., estuvo en el Castillo de Doña Blanca; a partir del s. vII y a comienzo del s. vi a.C. se ocupó Cádiz con finalidad productiva, comercial y religiosa.

A. Mederos (Ex Occidente Lux. El comercio micénico en el Mediterráneo Central y Occidental 1625-1100 a.C.), Complutum, 10, 1999, 229-266) cree que «las cerámicas de Llanete de los Moros (Córdoba) son simplemente los primeros ejemplares

${ }^{52}$ Los inicios de la escritura en la Península Ibérica. Grafitos en cerámicas del Bronce Final III y fenicias, Complutum 12, 2001, 96-112. 
seguros documentados en el Mediterráneo Occidental de un comercio claramente dirigido hacia la Península Ibérica desde el Mediterráneo Oriental (Levante, Chipre) y el Egeo (Grecia Meridional).

La búsqueda de metales en Occidente ha sido la razón siempre esgrimida como la motivación en la expansión del comercio micénico y minoico, en el Mediterráneo Central.

Desde nuestro punto de vista, la necesidad de disponer de fuentes alternativas de materias primas metálicas escasas y de gran valor como el estaño, la plata, el oro o el cobre, fue el principal motivo de las expediciones comerciales. No se trató de un comercio a la búsqueda de un recurso no disponible en las relaciones de origen, sino de la necesidad de acceder a fuentes alternativas, complementarias cuando existían encarecimientos, dificutlades o corte de suministro en las fuentes de aprovisionamiento habituales presentes en el Mediterráneo Oriental y el Próximo Oriente».

Estamos totalmente de acuerdo con estas ideas, que completan lo expuesto por J. Alvar. A. Mederos ofrece la siguiente cronología: Hio-Baiões (1150 Bronce Final). Huelva (950-925), Hierro I (950/925875).

Ya hace muchos años que los filólogos clásicos propusieron que la palabra micénica para estaño es de origen íbero. 